\title{
Physical Stability of Asphalt Emulsion Admix Seal Radon Barrier for Uranium Mill Tailings
}

\author{
T. E. Gates
}

September 1983

Prepared for the U.S. Department of Energy under Contract DE-AC06-76RLO 1830

Pacific Northwest Laboratory Operated for the U.S. Department of Energy by Battelle Memorial Institute 


\title{
DISCLAIMER
}

This report was prepared as an account of work sponsored by an agency of the United States Government. Neither the United States Government nor any agency thereof, nor any of their employees, makes any warranty, express or implied, or assumes any legal liability or responsibility for the accuracy, completeness, or usefulness of any information, apparatus, product, or process disclosed, or represents that its use would not infringe privately owned rights. Reference herein to any specific commercial product, process, or service by trade name, trademark, manufacturer, or otherwise, does not necessarily constitute or imply its endorsement, recommendation, or favoring by the United States Government or any agency thereof. The views and opinions of authors expressed herein do not necessarily state or reflect those of the United States Government or any agency thereof.

\author{
PACIFIC NORTHWEST LABORATORY \\ operated by \\ BATTELLE \\ for the \\ UNITED STATES DEPARTMENT OF ENERGY \\ under Contract DE-AC06-76RLO 1830
}

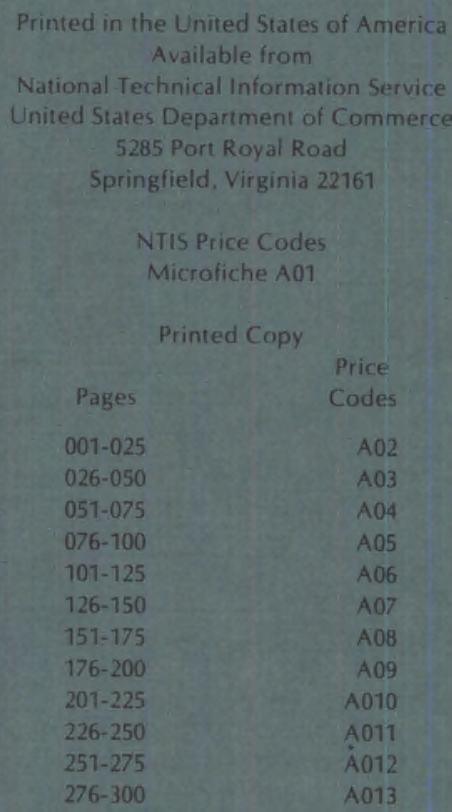


DOE/UMT - 0215

PNL -4846

UC -70

PHYSICAL STABILITY OF ASPHALT EMULSION ADMIX SEAL RADON BARRIER FOR URANIUM

MILL TAILINGS

T. E. Gates

September 1983

Prepared for

the U.S. Department of Energy

under Contract DE-AC06-76RLO 1830

Pacific Northwest Laboratory

Richland, Washington 99352 


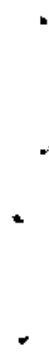




\section{SUMMARY}

Pacific Northwest Laboratory, under contract to the U.S. Department of Energy, is investigating the use of an asphalt emulsion admix seal to reduce the release of radon from uranium mill tailings. A key requirement of any cover system is its long-term stability; the cover must withstand fajlure over very long periods of time. An important determinant of overall cover system stability is the integrity of the $6.35-\mathrm{cm}(2.5-i n$.$) thick asphalt admix seal.$ Therefore, the physical stability of this seal was examined.

The investigation considered the mechanical interaction between the tailings pile and cover. The potential effect of differential settlement of the tailings pile on the integrity of the seal system was also examined.

Results indicate that the minimum span length the seal could withstand without failing is $0.34 \mathrm{~m}(1.1 \mathrm{ft})$. This assumes a differential settlement of $4.92 \mathrm{~cm}(1.94 \mathrm{in.})$ at the center resulting from the application of a $0.76-\mathrm{m}$ $(2.5-\mathrm{ft})$ cover. At spans greater than $0.60 \mathrm{~m}(1.97 \mathrm{ft})$, no tensile strain would develop. 


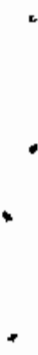




\section{ACKNOWLEDGMENTS}

This study was sponsored and supported by the U.S. Department of Energy under the Uranium Mill Tailings Remedial Action Project (UMTRAP) Technology Development Program. The author gratefully acknowledges the suggestions provided throughout the study by James Hartley, Program Manager, Pacific Northwest Laboratory (PNL). Special credit is due the Colorado State Highway Department for performing the core drilling and Charles Voss of PNL's Applied Mechanics and Structures Section for conducting part of the laboratory work. Special thanks are expressed to Ms. Linda Krumbah, who efficiently performed the word processing, Ms. Andrea Currie for the editing, and Curt Lavender for his general assistance. 


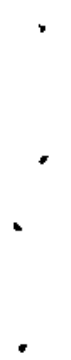




\section{CONTENTS}

\begin{tabular}{|c|c|c|c|c|c|c|c|c|c|c|c|c|c|}
\hline SUMMARY & . & - & . & $\cdot$ & • & • & $\cdot$ & - & $\cdot$ & $\cdot$ & $\cdot$ & $\theta$ & $i i i$ \\
\hline ACKNOWLED & GMENT & & . & $\cdot$ & $\cdot$ & - & $\cdot$ & $\cdot$ & - & $\cdot$ & $\cdot$ & 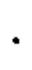 & v \\
\hline FIGURES & . & - & . & . & . & • & $\cdot$ & . & · & $\cdot$ & $\cdot$ & • & $i x$ \\
\hline TABLES & . & . & . & . & . & . & . & . & . & $\cdot$ & $\cdot$ & • & $i x$ \\
\hline NOTATIONS & . & . & . & . & . & . & . & . & $\cdot$ & . & $\cdot$ & & $x i$ \\
\hline INTRODUCT & ION & . & . & . & - & - & - & - & $\cdot$ & $\cdot$ & $\cdot$ & - & \\
\hline CONCLUSIO & & - & . & . & . & • & - & . & $\cdot$ & . & $\cdot$ & 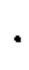 & \\
\hline TECHNOLOG & F FOR & UNS & ATURA & TED U & RAN IUM & MILL & TAILI & NGS & $\cdot$ & . & $\cdot$ & - & \\
\hline NATU & JRE OF & UNS & ATURAT & TED T & AILINGS & & . & - & $\cdot$ & . & - & ${ }^{\circ}$ & \\
\hline TAIL & INGS & PILE & 5. & . & - & . & - & - & - & . & • & ' & \\
\hline & Phys & ical & Conf & igura & tion & - & . & . & . & . & - & " & \\
\hline & Phys & ical & Prop & ertie & S . & · & • & . & $\cdot$ & - & - & $\theta^{\circ}$ & 8 \\
\hline PHYSICAL & PROPE & RT IE & $S O F$ & ASPHA & LT ADMI & IX SEA & & - & $\cdot$ & . & • & $\cdot$ & 1 \\
\hline DURA & ABILIT & & . & . & . & . & . & . & $\cdot$ & . & $\cdot$ & $\cdot$ & 2 \\
\hline STRE & ENGTH & . & . & . & . & . & - & . & $\cdot$ & . & • & • & 3 \\
\hline & Tria & xial & Comp & ressi & on Test & & . & . & . & $\cdot$ & $\cdot$ & $\cdot$ & \\
\hline & Flex & sibil & & · & - & - & · & - & $\cdot$ & . & • & $\cdot$ & 16 \\
\hline PERFORMAI & VCE OF & ASP & HALT & ADMIX & SEAL & . & . & . & . & . & • & • & 3 \\
\hline DIFF & ERENT & IAL & SETTL & EMENT & OF THE & E TAIL & LINGS & PILE & $\cdot$ & $\cdot$ & . & " & 23 \\
\hline ASPr & HALT S & $E A L$ & STABI & LITY & . & . & . & . & . & . & • & $\cdot$ & 24 \\
\hline REFERENCE & & . & . & . & . & . & . & . & . & $\cdot$ & • & · & 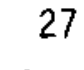 \\
\hline APPENDIX & $A-F$ & ORML & $\begin{array}{l}\text { ATIOI } \\
\text { AT IO }\end{array}$ & $\mathrm{NOF}$ & CONSOL I & & ON EQU & JAT ION & & • & * & & A. 1 \\
\hline
\end{tabular}


• .

. 


\section{FIGURES}

1 Stress Distribution During Desiccation of a Soil . . . 6

2 Typical Tailings Pile Cross Section . . . . . . . 7

3 Direct Shear Test - Grand Junction, Colorado, Tailings . . 8

4 Direct Shear Test - Salt Lake City, Utah, Tailings. . . 9

5 Asphalt Emulsion Radon Barrier System . . . . . . . . 11

6 Effective Stress Envelopes for Asphalt Admix Seal . . . 14

7 Shear Strength Versus Temperature . . . . . . 15

8 Creep Rate Versus Applied Load at $25^{\circ} \mathrm{C}\left(77^{\circ} \mathrm{F}\right) \quad$. $\quad . \quad 17$

9 Creep Rate Versus Various Loads and Temperatures . . . 17

10 Percentage Elongation (Deflection) Versus Time . . . 19

11 Modulus of Rupture Versus Temperature . . . . . . 22

12 Percentage Elongation Versus Span . . . . . . 25

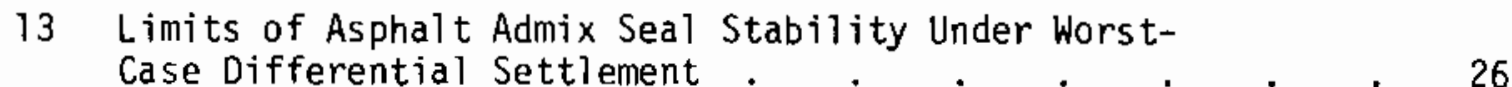

\section{$\underline{\text { TABLES }}$}

1 Typical Values of Unit Weight and Friction Angle for Soil Backfill . . . . . . . . . . . . 9

2 Creep Rate at Various Loads and Temperatures . . . . 18

3 Percentage Elongation at Yield and Failure . . . . . 19

4 Flexural Strength Test . . . . . . . . . . . 21

5 Expected Settlement of Tailings Pile . . . . . 24 


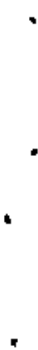




\section{NOTATIONS}

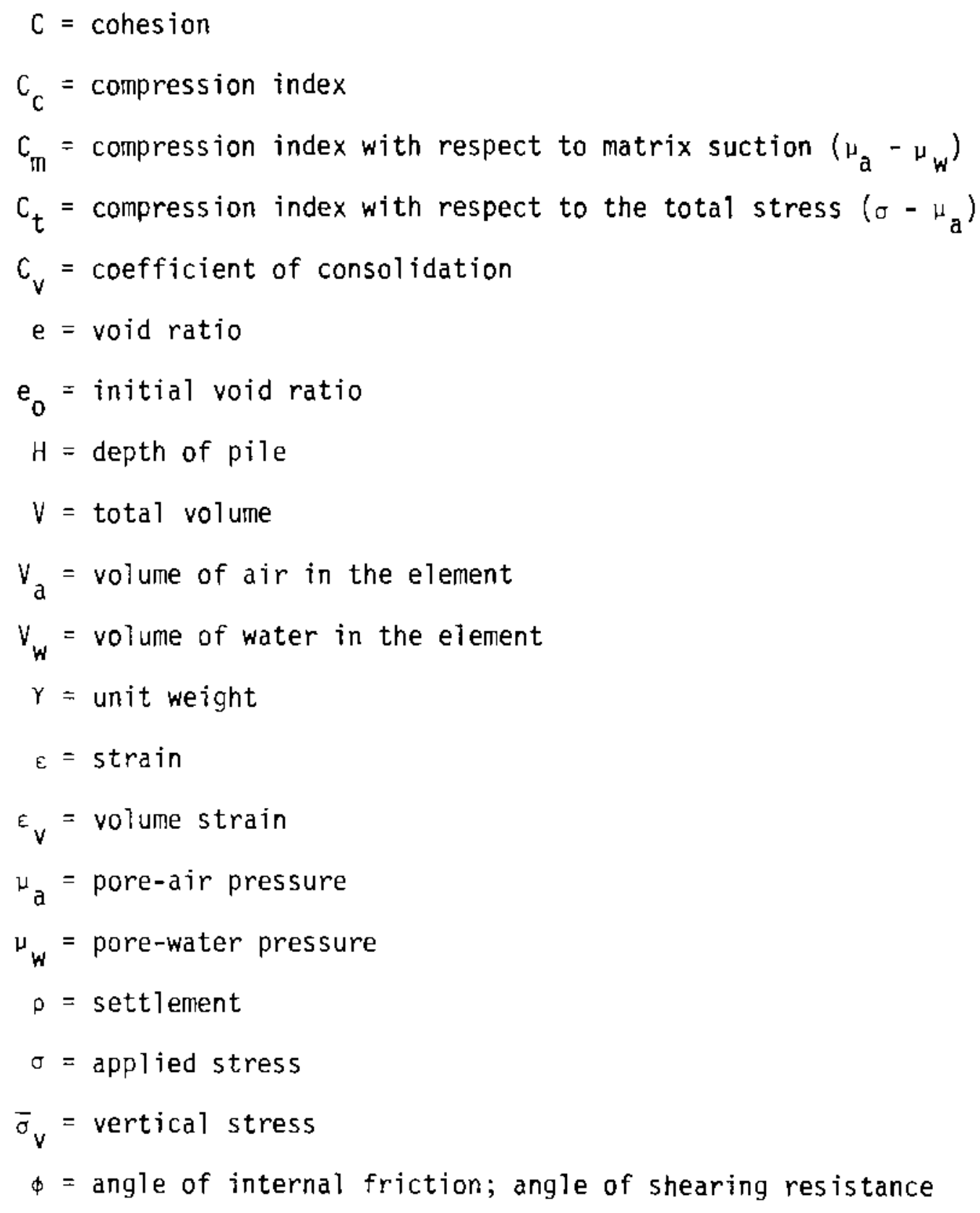




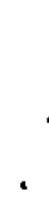




\section{PHYSICAL STABILITY OF ASPHALT EMULSION}

ADMIX SEAL RADON BARRIER FOR

URANIUM MILL TAILINGS

\section{INTRODUCTION}

Cover systems used to reduce radon release from uranium mill tailings must be able to withstand the differential settlement that can occur within the tailings pile without sustaining adverse effects upon the cover's radon attenuation characteristics. It follows then, that the asphalt admix seal (Baker 1983; Hartley 1980, 1981, 1983) should be considered with respect to the material or purpose for which it is to be used, implying that optimal performance can be secured only by mutual adaptation of one to the other.

At the request of the U.S. Department of Energy (DOE), the Pacific Northwest Laboratory $(P N L)^{(a)}$ conducted a study to examine the physical stability of the asphalt admix seal. Consideration was given to the mechanical interaction between the tailings pile and cover. Because of the property differences among the siimes, sands, and intermediate zones, differential settiement is expected to occur across the surface of the pile. The anticipated effect of this differential settlement on the integrity of an asphalt admix seal system was part of the investigation.

This report first presents the conclusions about the stability of the asphalt seal. Next, the nature of unsaturated tailings and characteristics of the tailings pile are described. The fourth section presents laboratory test results obtained from sampies from the 1981 Grand Junction, Colorado, asphalt emulsion test site. The expected performance of the asphalt admix seal with respect to differential settlement is analyzed in the final section.

(a) Operated for the U.S. Department of Energy by Battelle Memorial Institute 


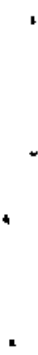




\section{CONCLUSIONS}

Differential settlement is expected to occur across the surface of the uranium mill tailings pile due to differences in properties among the slimes, sands, and intermediate zones. The physical stability of the asphalt admix seal is important; the seal must be able to withstand the differential settlement without sustaining adverse effects to radon attenuation characteristics.

Based on the results of this study, four primary conclusions were drawn about the stability of the asphalt admix seal:

- The asphalt membrane will retain its tough, flexible qualities indefinitely while buried under a protective cover. Once exposed to the atmosphere, however, surface changes will occur. The rapidity will, of course, vary depending upon specific atmospheric conditions.

- The effect of temperature on the shear strength of the asphalt admix material is significant. A two orders of magnitude change in shear strength was observed over a temperature span of $10^{\circ} \mathrm{C}\left(50^{\circ} \mathrm{F}\right)$.

- The minimum span length the asphalt admix seal could withstand without failing is $0.34 \mathrm{~m}(1.1 \mathrm{ft})$. This conclusion is based on the assumption that a differential settlement of $4.92 \mathrm{~cm}$ (1.94 in.) for a tajlings zone composed of a $60 \%$ sands $/ 40 \%$ slimes would occur from the application of a $0.76-m(2.5-f t)$ cover.

- None of the samples tested would reach its yield point at spans greater than $0.60 \mathrm{~m}(1.97 \mathrm{ft})$. Hence, no tensile strain would develop. This conclusion neglects the membrane stresses and possible scaling effects.

Overall, this study demonstrated that the differential settlement expected to occur across the surface of the uranium mill tailings pile, as well as the temperature range that might be expected, would not adversely affect the long-term radon attentuation capabilities of the asphalt admix sea]. 


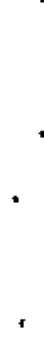




\section{TECHNOLOGY FOR UNSATURATED URANIUM MILL TAILINGS}

The field of soil mechanics consists of the studies of saturated and of unsaturated soils. The differences between unsaturated and saturated soils result from the surface tension forces that are present in unsaturated and multiphase porous systems, but are absent under saturated conditions. Only two phases are involved in the saturated systems; i.e., the solid or skeleton phase of the porous material and the liquid phase that fills the pore space. In the unsaturated (multiphase) systems, a third phase, in which gas is immiscible with the water in the soil pores, is involved. The differences between unsaturated and saturated conditions that affect settlement are caused by the capillary forces arising from the continuous air-water interface within the porous material. The presence of an air-water interface, involving surface tension, results in more involved soil mechanics and fluid flow properties that must be considered in an analysis of the settlement and flow in unsaturated systems.

Saturated and unsaturated conditions are involved in the uranium mill tailings management evaluation; however, the more involved unsaturated region is probably of more importance. The unsaturated category commonly encompasses natural, desiccated soils; compacted soils; and dewatered uranium mill tailings. These soils generally have negative pore-water pressures. The natural tendency of unsaturated uranium mill tailings to shrink and swell, due to changing environmental conditions, leads to their most prevalent stability problems.

\section{NATURE OF UNSATURATED TAILINGS}

Many soil deposits are originally saturated. Tailings material, like lacustrine deposits, is deposited at water contents above its liquid limit and is consolidated by the weight of the overlying sediments. The sediments begin to desiccate as the tailings dry through dewatering and evaporation. The pore-water pressure, in turn, decreases while the total stress on the sediments remains essentially constant (Figure 1). The pore-water pressure becomes negative as a result of the capillary force associated with the 


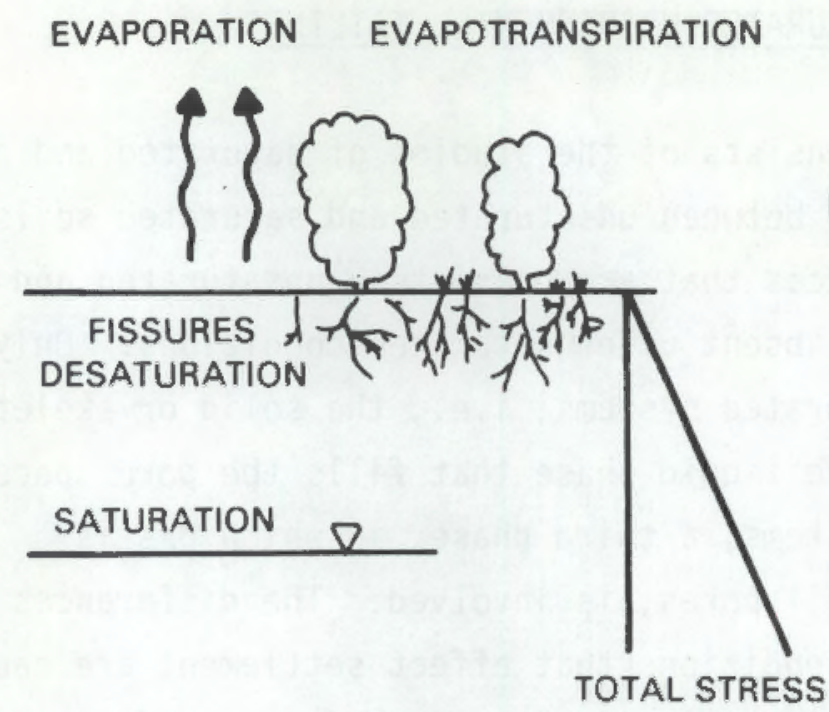

$(\sigma)$

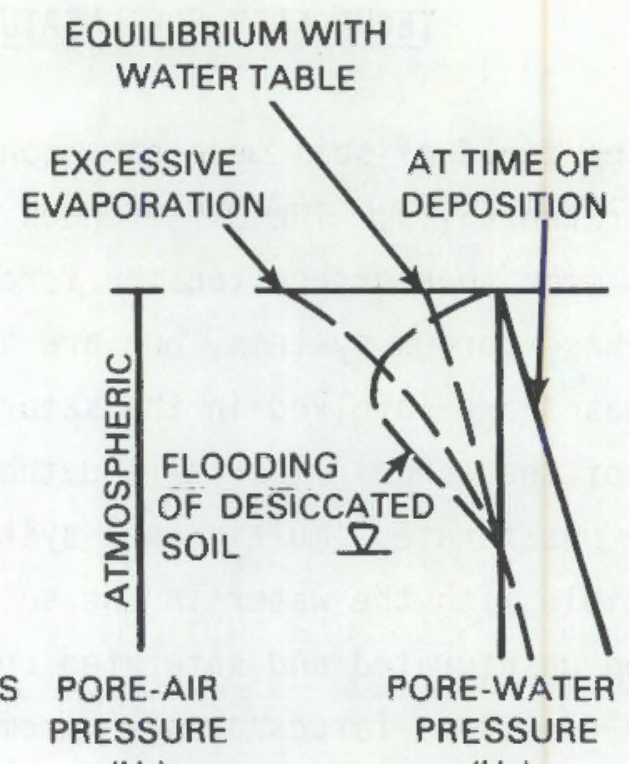

$\left(U_{n}\right)$

$\left(U_{w}\right)$

FIGURE 1. Stress Distribution During Desiccation of a Soil (Fredlund 1979)

air-water interface above the water table, leading to consolidation of the sediments. If grasses, plants, or brush are permitted to grow on the tailings pile before cover placement, the tailings are consolidated and desaturated further by evapotranspiration.

If the tension in the water phase exceeds the lateral confining pressure in the soil mass, a secondary mode of desaturation, cracking, can occur. Desaturation can also occur if the tailings' material structure is subjected to tensile stresses by remolding during the consolidation process.

A tailings deposit is constantly subjected to changing environmental conditions. These environmental changes cause the tailings deposit to shrink and swell before cover placement. This results from changes in the pore-water pressure distribution, which can take on a wide variety of shapes (Figure 1).

\section{TAILINGS PILES}

The physical configuration and properties vary among tailings piles as well as within a single tailings pile. During the active life of the tailings, changes in milling and waste management methods often account for 
such variability. Other parameters responsible for variability in tailings are the mineralogy of the feed ore, characteristics of the milling operation, method of tailings emplacement, and post-operational treatment. A complex system is developed among the properties inherent to the tailings pile by hydrographic, geologic, and climatic conditions.

\section{Physical Configuration}

In general, the tailings consists of two basic materials: nonplastic silt-size slimes and fine, uniform sands. Different tailings zones are formed during tailings emplacement (Figure 2). Interbedded layers of the sands and slimes and mixtures of these materials comprise these zones. Most sites contain either large deposits of sands, with few fines, or interbedded sand-slime layers. Zones in which the materials are mixed are difficult to distinguish. Few extensive deposits with only slimes exist. The deposition pattern is governed by the outlet location. The percentage of sand, silt, and clay, in addition to the layering of the tailings material in the disposal pit, depends on the nature of the parent materials, the characteristics of the milling operation, and the method of the tailings placement.

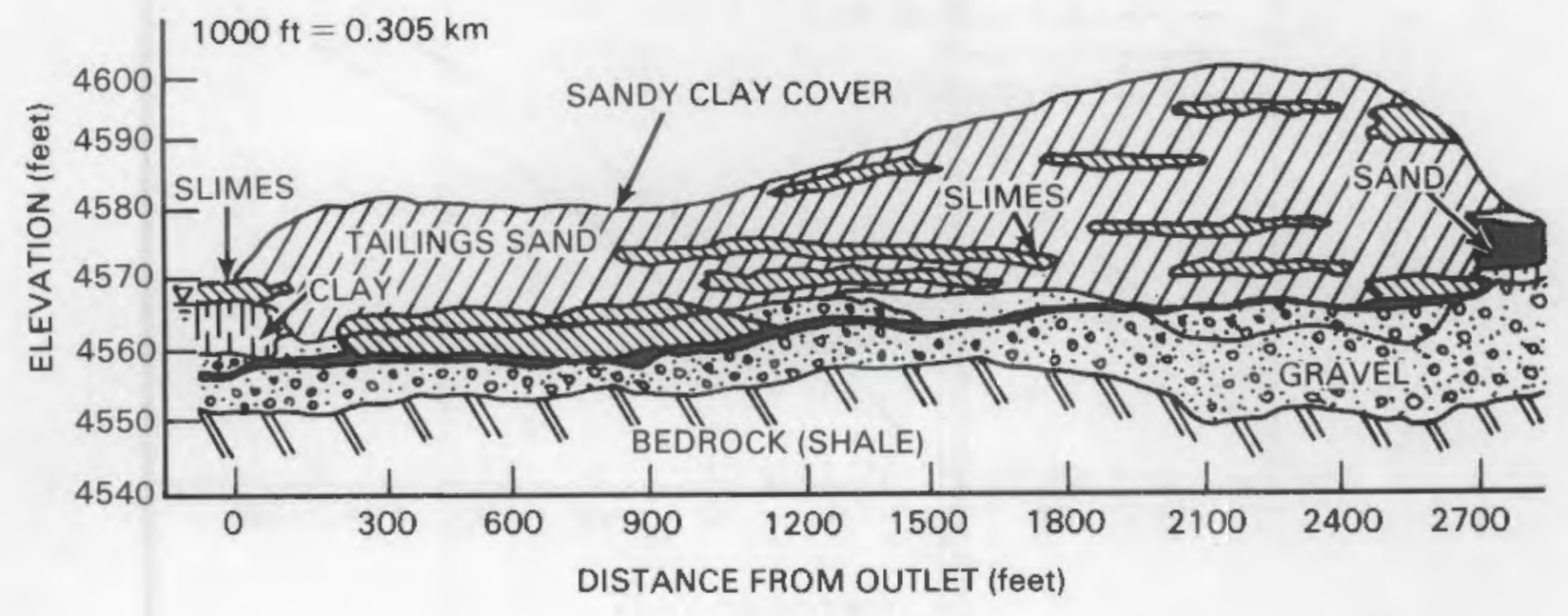

FIGURE 2. Typical Tailings Pile Cross Section (CSU 1980) 


\section{Physical Properties}

Because some of the coarser tailings could be included in the structural enclosure beneath protective covers, remolded shear strength of the tailings is a property of considerable importance. Tests performed by Colorado State University (CSU 1980) have shown that residual friction angles are in the range of the peak for the low densities (Figures 3 and 4 ). These unusualiy high values, specifically for the silt-size slimes, were attributed to a high degree of interlock and few large voids, although these materials are not well graded in the normal sense. The friction angles reported for different void ratios (dry density) are comparable to those of typical backfill soils (Table 1).

Moisture content varies widely in the tailings material. The sands are primarily in the 3 to $9 \%$ (dry wt) range and the extended slime deposits in the 30 to $45 \%$ (dry wt) range (CSU 1980). Where sand lenses provide drainage for slime layers, but are unable to drain freely, intermediate values of moisture content may be found.

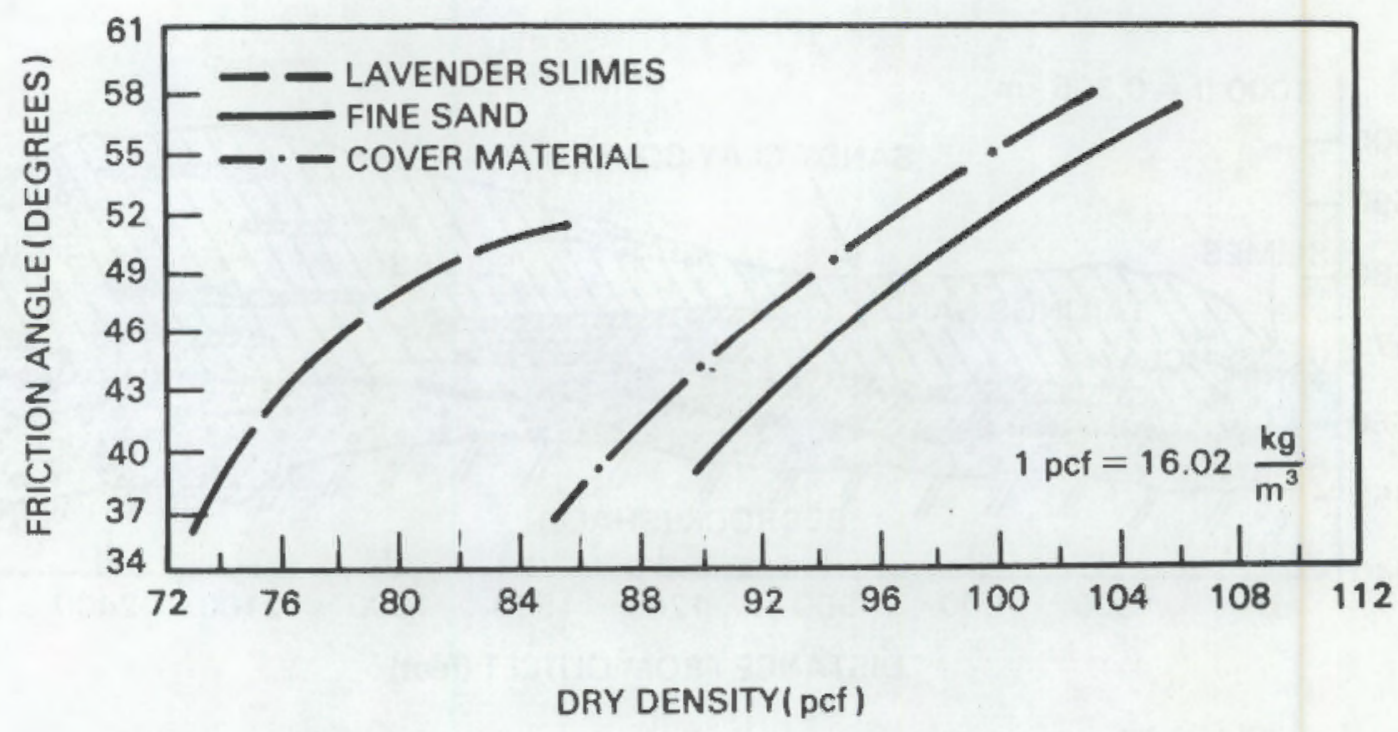

FIGURE 3. Direct Shear Test - Grand Junction, Colorado, Tailings (CSU 1980) 


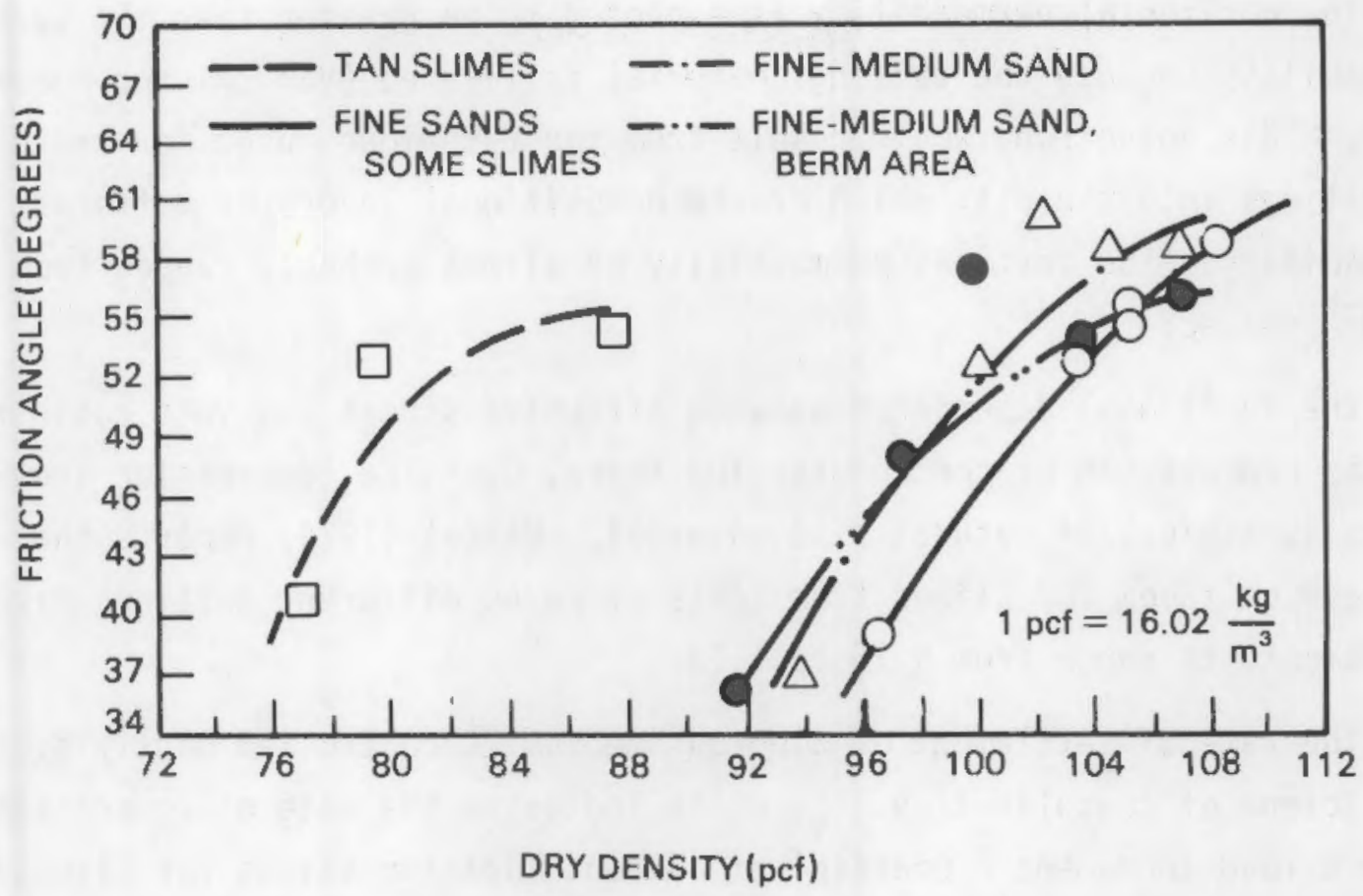

FIGURE 4. Direct Shear Test - Salt Lake City, Utah, Tailings (csi 1980)

TABLE 1. Typical Values of Unit Weight and Friction Angle for Soil Backfill (Spangler and Handy 1973)

\begin{tabular}{|c|c|c|c|}
\hline Backfill Material & $\begin{array}{l}\text { Unijt W } \\
\mathrm{kg} / \mathrm{m}^{3}\end{array}$ & ht $\begin{array}{r}\gamma, \\
(p c f)\end{array}$ & $\begin{array}{l}\text { Internal Friction } \\
\text { Angle } \phi \text {, degrees }\end{array}$ \\
\hline Soft plastic clay & $1682-1922$ & $(105-120)$ & $0-10$ \\
\hline Wet, fine silty sand & $1762-1922$ & $(110-120)$ & $15-30$ \\
\hline Dry sand & $1442-1762$ & $(90-110)$ & $25-40$ \\
\hline Gravel & $1922-2162$ & $(120-135)$ & $30-40$ \\
\hline Loose loam & $1201-1442$ & $(75-90)$ & $30-45$ \\
\hline Compact loam & $1442-1602$ & $(90-100)$ & $30-45$ \\
\hline Compact clay & $1442-1762$ & $(90-110)$ & $25-45$ \\
\hline Cinders & 641 & $(40)$ & $25-45$ \\
\hline Compact sand-clay & $1842-2002$ & $(115-125)$ & $40-50$ \\
\hline Water & 1000 & $(62.4)$ & 0 \\
\hline
\end{tabular}


The horizontal permeability is expected to be greater than the vertical permeability because the tailings material is layered (Van Zyl and Robertson 1980). This anisotropy would result from the techniques used for the disposal of tailings into the pit, which create depositional layers of differing permeability. The vertical permeability of slimes probably ranges from $10^{-4}$ to $10^{-6} \mathrm{~cm} / \mathrm{sec}$.

The functional dependence between effective stress and void ratio for a soil is represented by the compression index, $C_{c}$. The compression index of slimes is typical of natural silt material. Mittal (1974) reports the compression index for slimes from tests of seven different tailings disposal embankments to range from 0.25 to 1.13 .

The rate of settlement of a porous medium is controlled partly by the coefficient of consolidation, $C_{v}$, which indicates the rate of compression under a load increment. Coefficient of consolidation values for slimes have been reported from $10^{-1}$ to $10^{-3} \mathrm{~cm}^{2} / \mathrm{sec}$ (Mittal 1974). 
PHYSICAL PROPERTIES OF ASPHALT ADMIX SEAL

The physical properties of asphalt admix seals are generally dependent upon stress conditions and temperature. The ingredients that comprise asphalt admixes have completely different characteristics. Most of the mix is made up of primarily elastic mineral aggregate. The asphalt portion, however, behaves as a viscous liquid at high temperatures or under sustained loads, and as an elastic material at low temperatures or when subjected to impact loads. Hence, asphalt admixes have both elastic and plastic properties.

The bituminous asphalt in seals applied over uranium mill tailings piles must serve two primary functions:

- act as a permanent binder

- provide a lasting barrier against radon release and water transport in both 1 iquid or vapour form.

A typical asphalt admix cover system is shown in Figure 5.

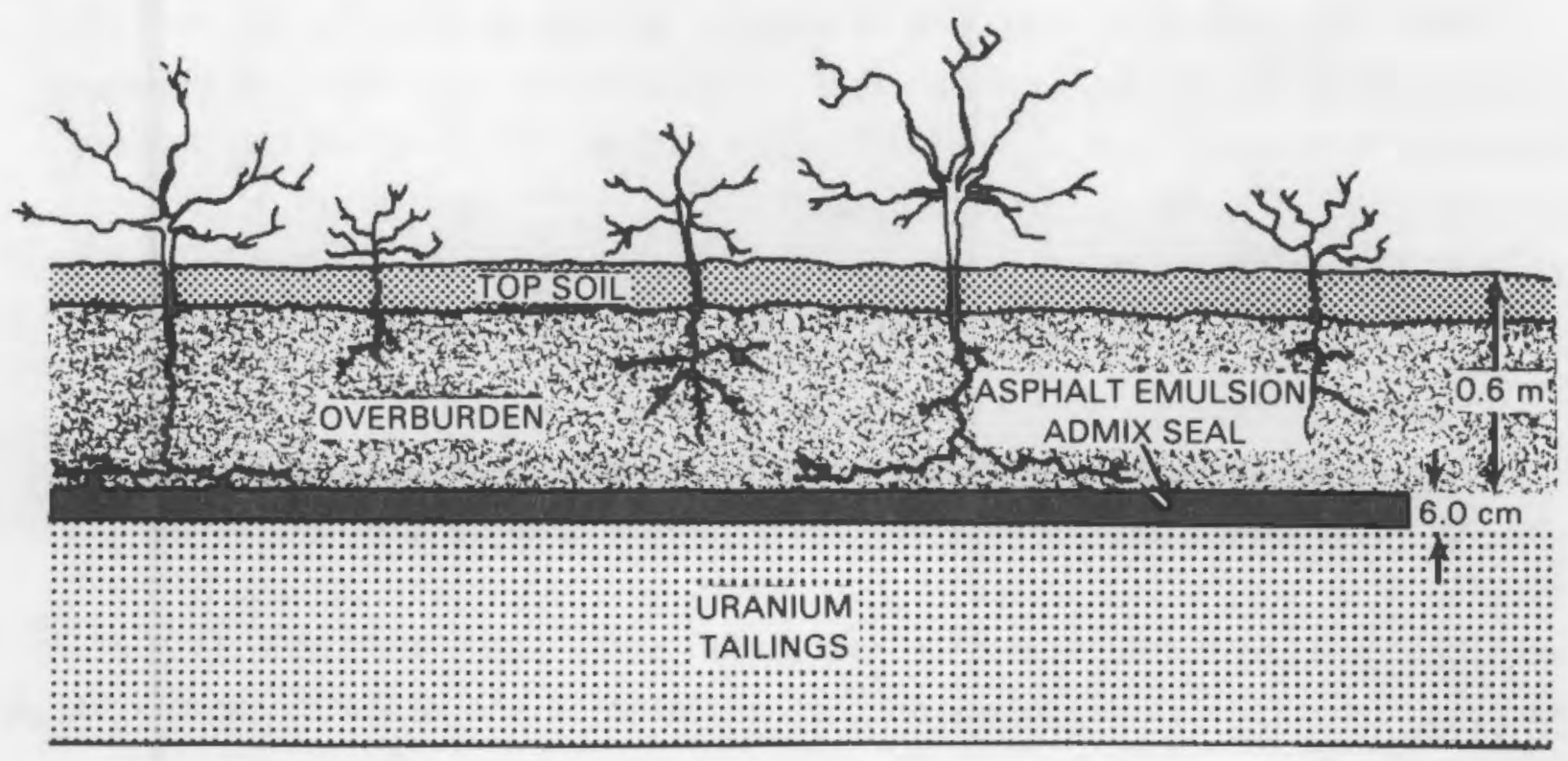

FIGURE 5. Asphalt Emulsion Radon Barrier System 


\section{DURABILITY}

From very early time bituminous substances have been known to man. Biblical references indicate their uses as a cement and waterproofing material. Bituminous substances used as paving material and wood preservative for ships have been discovered during the excavation of ancient cities along the Mediterranean (Abraham 1945).

The U.S. Bureau of Reclamation, in cooperation with the asphalt industry, was the first to develop buried asphalt membrane construction. They sought an efficient and economical means of controlling seepage in earth-lined irrigation canals and laterals. Some of these linings are still in satisfactory condition after more than 25 years of service.

An asphalt membrane will retain its tough, flexible qualities indefinitely while buried under a protective cover. Archaeological excavations indicate that asphalt coatings undergo no appreciable deterioration during thousands of years in the dark; however, when the material is exposed to light, rapid surface changes occur (Abraham 1945).

When the bituminous compound is exposed to the atmosphere, the influence of air and light becomes very apparent. The consequent changes are assessed using various means such as estimating the rate of "rusting" of the surface and the rate of hardening of the bitumen. Naturally, from a practical viewpoint, the most important criterion is the consequence of such changes; will they prevent the bitumen layer from performing its primary function?

Adequate compaction of asphalt admix seals is absolutely necessary if they are to be structurally sound, watertight, and gastight. Unlike asphalt pavement for roads, the asphalt seal will not be compacted further under traffic after it is in service. Thus, it is most important to obtain the required density at the time of construction because the impermeability of an asphalt admix seal is dependent on the reduction of the voids in the mix below a certain value. 


\section{STRENGTH}

The stability or load-carrying capacity of asphalt is determined by its strength characteristics. Strength of asphalt admix seals has been quantified using several parameters and tests; e.g., creep, modulus values, and triaxial shear strength. The samples used for testing by the University of New Mexico and PNL were collected from the 1981 asphalt emulsion test site located on the uranium mill tailings pile in Grand Junction, Colorado.

Triaxial Compression Test

Figure 6 presents a summary of triaxial compression tests performed by the University of New Mexico (UNM). This summary reflects information provided by D. J. Hamberg of UNM on August 19, 1981. A11 cores were $3.8 \mathrm{~cm}$ (1.5 in.) in diameter and trimed to $7.6-\mathrm{cm}$ (3-in.) lengths. A strain rate of $1 \%$ per minute was used for all tests.

Typically the failure envelope is curved, based upon total stresses. Thus, the angle of internal friction $(\phi)$ and cohesion $(C)$ are often only for the higher confining stresses. Tests by the UNM provided strength parameters of $\mathrm{C}=8.3$ to $769 \mathrm{kPa}(1.2$ to $111.5 \mathrm{psi})$ and $\phi=4$ to $16^{\circ}$ at the respective test temperatures.

The effect of temperature on the shear strength of the asphalt admix material is significant, as noted by the strength parameters. Shear strengths in the range of 6.9 to $27.6 \mathrm{kPa}$ ( 1 to $4 \mathrm{psi}$ ) were determined at $24^{\circ} \mathrm{C}\left(75^{\circ} \mathrm{F}\right)$, 172 to $241 \mathrm{kPa}(25$ to $35 \mathrm{psi})$ at $10^{\circ} \mathrm{C}\left(50^{\circ} \mathrm{F}\right)$, and 1000 to $1172 \mathrm{kPa}$ (145 to 170 psi) at $-4^{\circ} \mathrm{C}\left(25^{\circ} \mathrm{F}\right)$. A two orders of magnitude change in shear strength was observed over a temperature span of $10^{\circ} \mathrm{C}\left(50^{\circ} \mathrm{F}\right)$.

A semilog plot of shear strength versus temperature is shown in Figure 7. For each of the four confining stresses, exponential curve-fitting was based upon three data points at the respective test temperatures. High degrees of correlation between ordinate and abscissa data are shown. The regression lines and corresponding constants are also shown in Figure 7. 


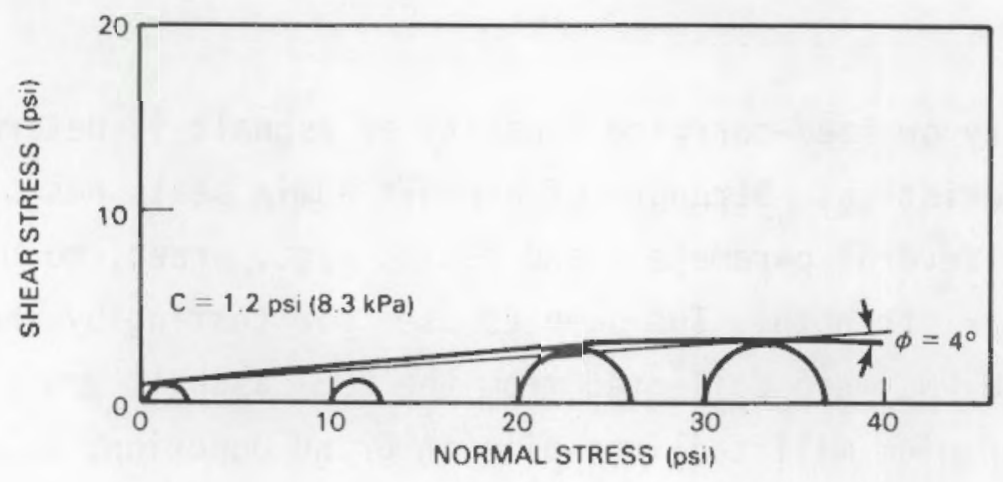

(a) Asphalt Admix Seal at $24^{\circ} \mathrm{C}\left(75^{\circ} \mathrm{F}\right)$ $1 \mathrm{ps} i=6.9 \mathrm{kPa}$

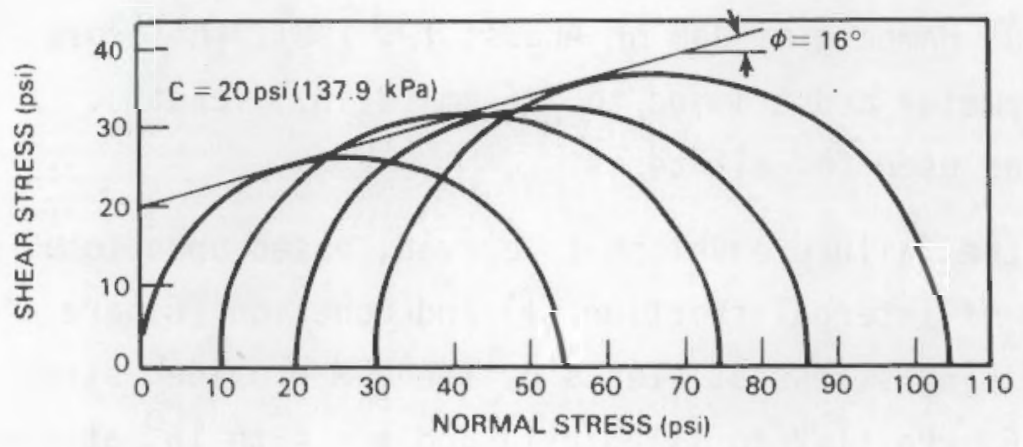

(b) Asphalt Admix Seal at $10^{\circ} \mathrm{C}\left(50^{\circ} \mathrm{F}\right)$ 1 psi $=6.9 \mathrm{kPa}$

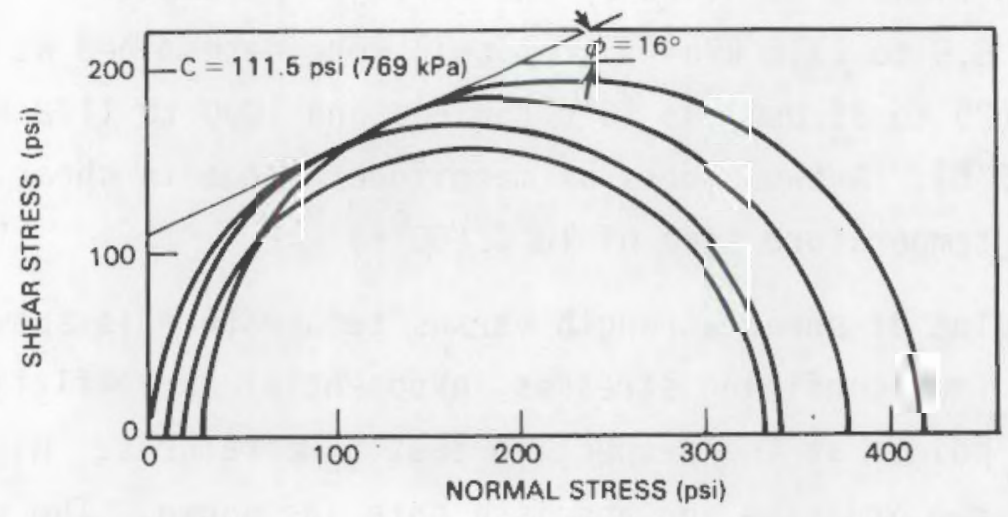

(c) Asphalt Admix Seal at $-4^{\circ} \mathrm{C}\left(25^{\circ} \mathrm{F}\right)$ $1 \mathrm{psi}=6.9 \mathrm{kPa}$

FIGURE 6. Effective Stress Envelopes for Asphalt Admix Seal 


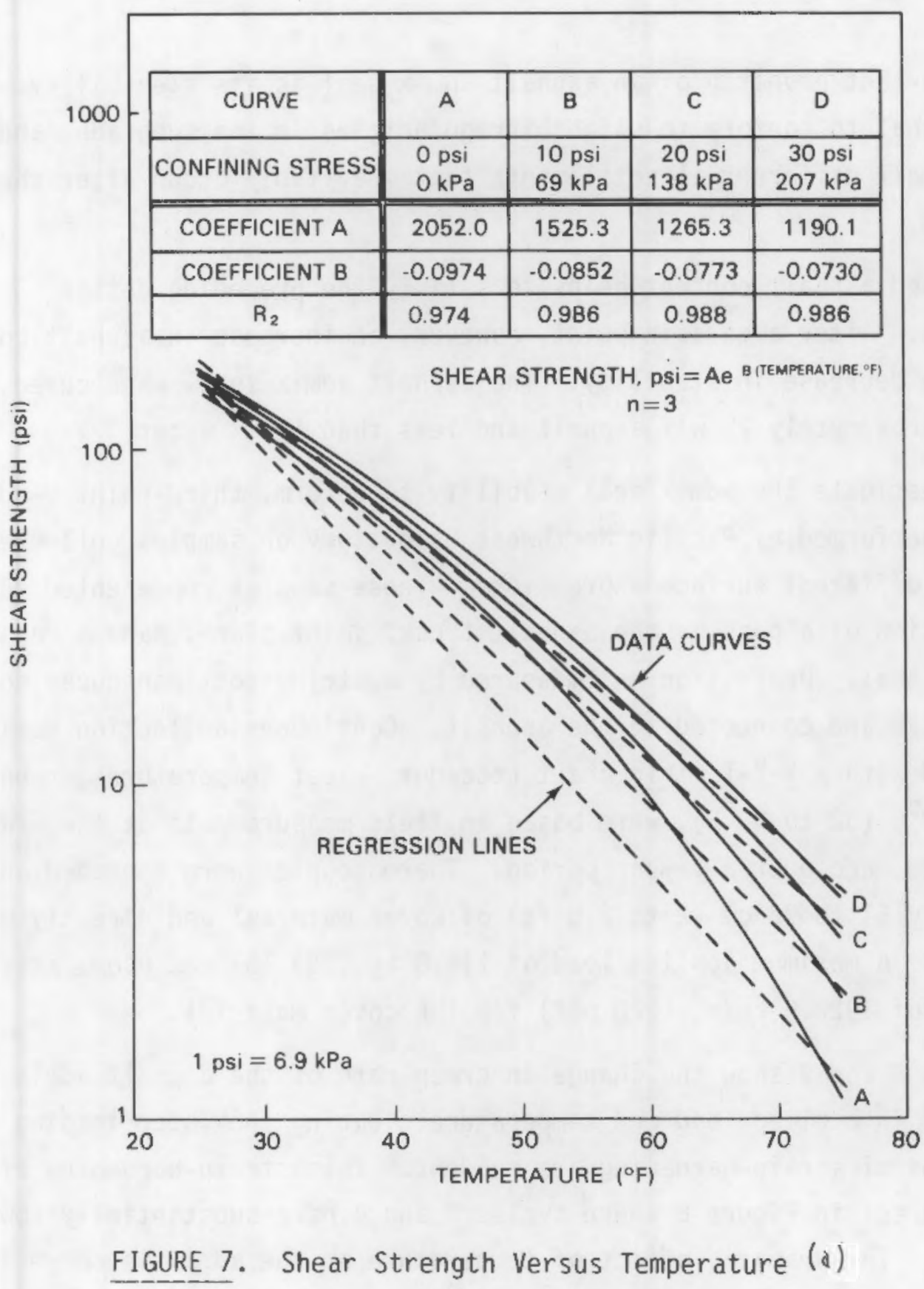

(a) Information provided by Debora J. Hamberg, University of New Mexico, Albuquerque, New Mexico, on August 19, 1981. 


\section{Flexibility}

An important property of an asphalt admix seal is its flexibility. This allows the seal to conform to slight irregularities in the subgrade, and to adjust to small differential settlements that inevitably occur after the cover is completed.

Increased asphalt content helps to satisfy the preceding design requirements. After a certain point, however, an increase in asphalt content results in a decrease in stability. The asphalt admix seal, when cured, contains approximately $22 \mathrm{wt} \%$ asphalt and less than $1 \mathrm{wt} \%$ water.

To investigate the admix seal's ability to deform, third-point bending tests were performed by Pacific Northwest Laboratory on samples collected over a number of different surface expressions. These samples represented the central portion of a pass by the asphalt truck, joint planes, and a repaired area of the seal. Deflection was measured by a string-pot transducer mounted above the slab and connected to the asphalt. Continuous deflection monitoring was achieved with a $Y-Y-T$ strip chart recorder. Test temperatures, ranging from 0 to $28^{\circ} \mathrm{C}$ ( 32 to $82^{\circ} \mathrm{F}$ ), were based on field measurements at the Grand Junction site made over a 1 -year period. Thermocouples were embedded under approximately 61 to $76 \mathrm{~cm}$ ( 2 to $2.5 \mathrm{ft}$ ) of cover material and directly over the asphalt. A maximum applied load of $114.8 \mathrm{~kg}(253 \mathrm{lb})$ was used, assuming a unit weight of $1922.6 \mathrm{~kg} / \mathrm{m}^{3}$ (120 pcf) for the cover material.

Figures 8 and 9 show the change in creep rate of the asphalt admix seal with changes in applied load and temperature. During the later loading cycles, signs of strain-hardening are evident. This strain-hardening effect is most apparent in Figure 8 where cycles 3 and 4 have substantially lower creep rates. The dramatic effect of temperature on the admix is shown in Figure 9 , where the creep rate at $25^{\circ} \mathrm{C}\left(77^{\circ} \mathrm{F}\right)$ is an order of magnitude greater than at $6^{\circ} \mathrm{C}\left(43^{\circ} \mathrm{F}\right)$. Creep rates for other samples at various temperatures are given in Table 2. 


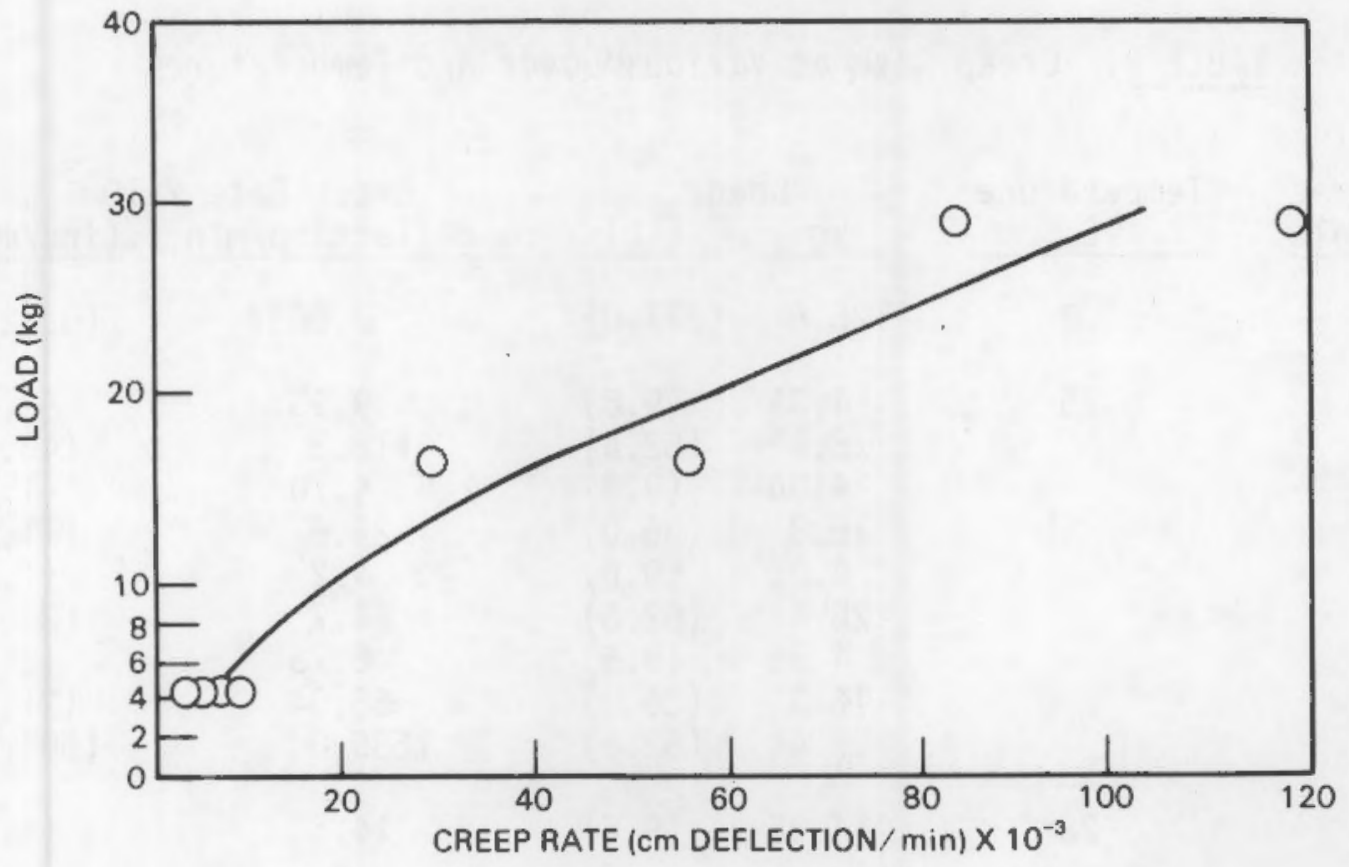

FIGURE 8. Creep Rate Versus Applied Load at $25^{\circ} \mathrm{C}\left(77^{\circ} \mathrm{F}\right)$

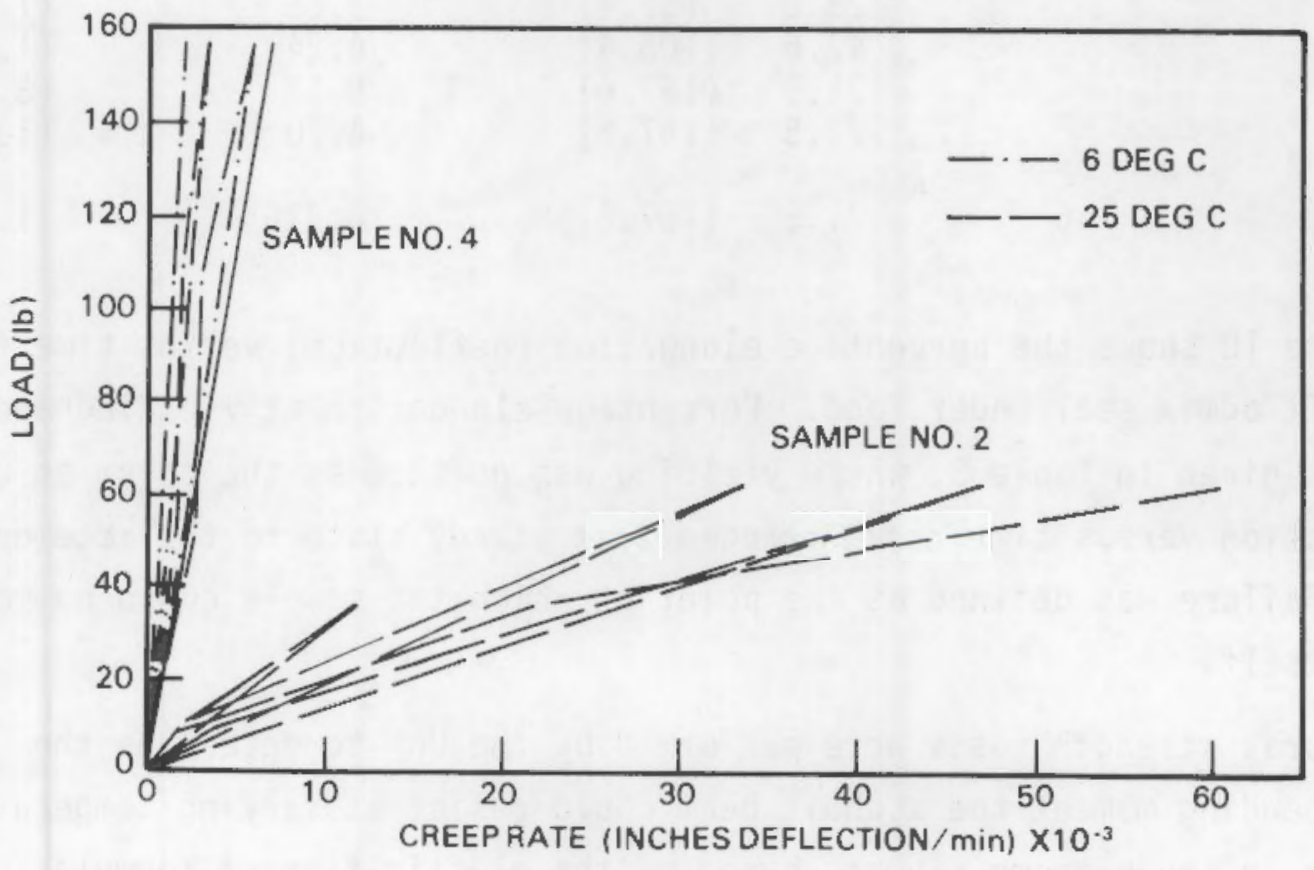

FIGURE 9. Creep Rate Versus Various Loads and Temperatures 
TABLE 2. Creep Rate at Various Loads and Temperatures

\begin{tabular}{|c|c|c|c|c|c|}
\hline Sample & $\begin{array}{l}\text { Temperature } \\
\text { OC }\end{array}$ & $\mathrm{kg}^{\mathrm{LO}}$ & (1b) & $\begin{array}{c}\text { Creep Rate } x \\
\mathrm{~cm} \text { deflection/min }\end{array}$ & $\begin{array}{l}10^{-3} \\
\text { (in./min) }\end{array}$ \\
\hline 1 & 0 & 125.6 & $(277.0)$ & 0.0637 & $(0.0251)$ \\
\hline 2 & 25 & $\begin{array}{c}4.35 \\
28.4 \\
4.35 \\
16.3 \\
4.35 \\
28.4 \\
4.35 \\
16.3 \\
28.4\end{array}$ & $\begin{array}{r}(9.6) \\
(62.6) \\
(9.6) \\
(36.0) \\
(9.6) \\
(62.6) \\
(9.6) \\
(36.0) \\
(62.6)\end{array}$ & $\begin{array}{c}9.95 \\
118.3 \\
4.70 \\
29.6 \\
4.2 \\
84.7 \\
6.76 \\
55.04 \\
1535.0\end{array}$ & $\begin{array}{r}(3.92) \\
(46.57) \\
(1.85) \\
(11.67) \\
(1.66) \\
(33.33) \\
(2.66) \\
(21.67) \\
(604.20)\end{array}$ \\
\hline 3 & 28 & 4.35 & $(9.6)$ & 14.5 & $(5.70)$ \\
\hline 4 & 6 & $\begin{array}{l}23.6 \\
47.6 \\
71.5 \\
71.5 \\
23.6 \\
47.6 \\
71.5 \\
71.5\end{array}$ & $\begin{array}{r}(52.4) \\
(105.4) \\
(157.6) \\
(157.6) \\
(52.4) \\
(105.4) \\
(157.6) \\
(157.6)\end{array}$ & $\begin{array}{c}6.50 \\
7.10 \\
14.5 \\
16.9 \\
3.86 \\
4.24 \\
8.15 \\
4.70\end{array}$ & $\begin{array}{l}(2.56) \\
(2.78) \\
(5.71) \\
(6.67) \\
(1.52) \\
(1.67) \\
(3.21) \\
(1.85)\end{array}$ \\
\hline 5 & 6 & 71.5 & $(157.6)$ & 0.416 & $(1.64)$ \\
\hline
\end{tabular}

Figure 10 shows the percentage elongation (deflection) versus time for the asphalt admix seal under load. Percentage elongation at yielding and failure is given in Table 3 , where yielding was defined as the point at which the deflection versus time curve changed from steady state to the accelerating region. Failure was defined as the point at which the sample could no longer support itself.

Flexural strength tests were performed by the UNM to determine the ultimate bending moment the asphalt beam could resist at varying temperatures. The stress in the extreme fibers, based on the elastic flexure formula for the experimentally determined ultimate bending moment, is called the rupture 


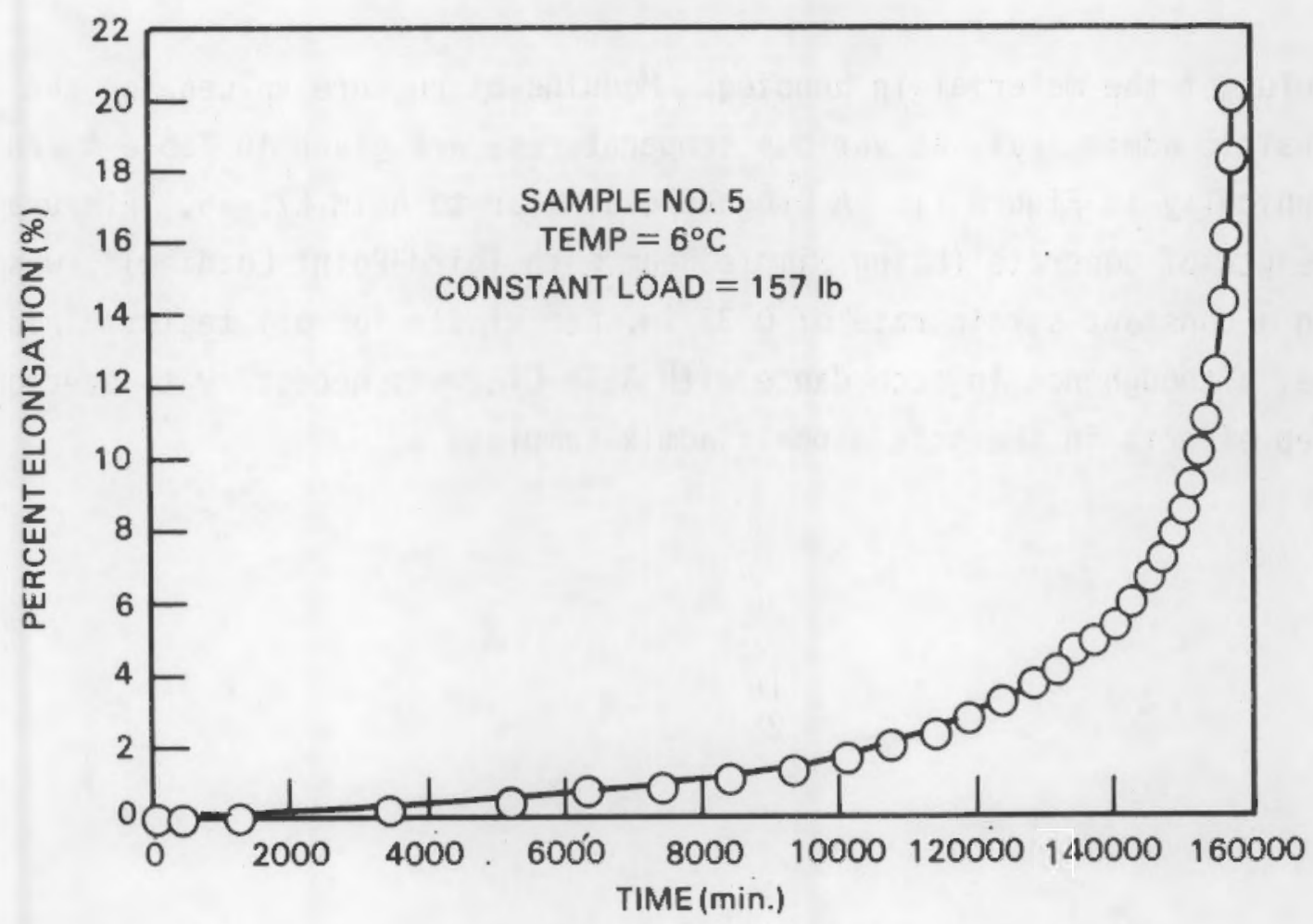

FIGURE 10. Percentage Elongation (Oeflection) Versus Time

TABLE 3. Percentage Elongation at Yield and Failure

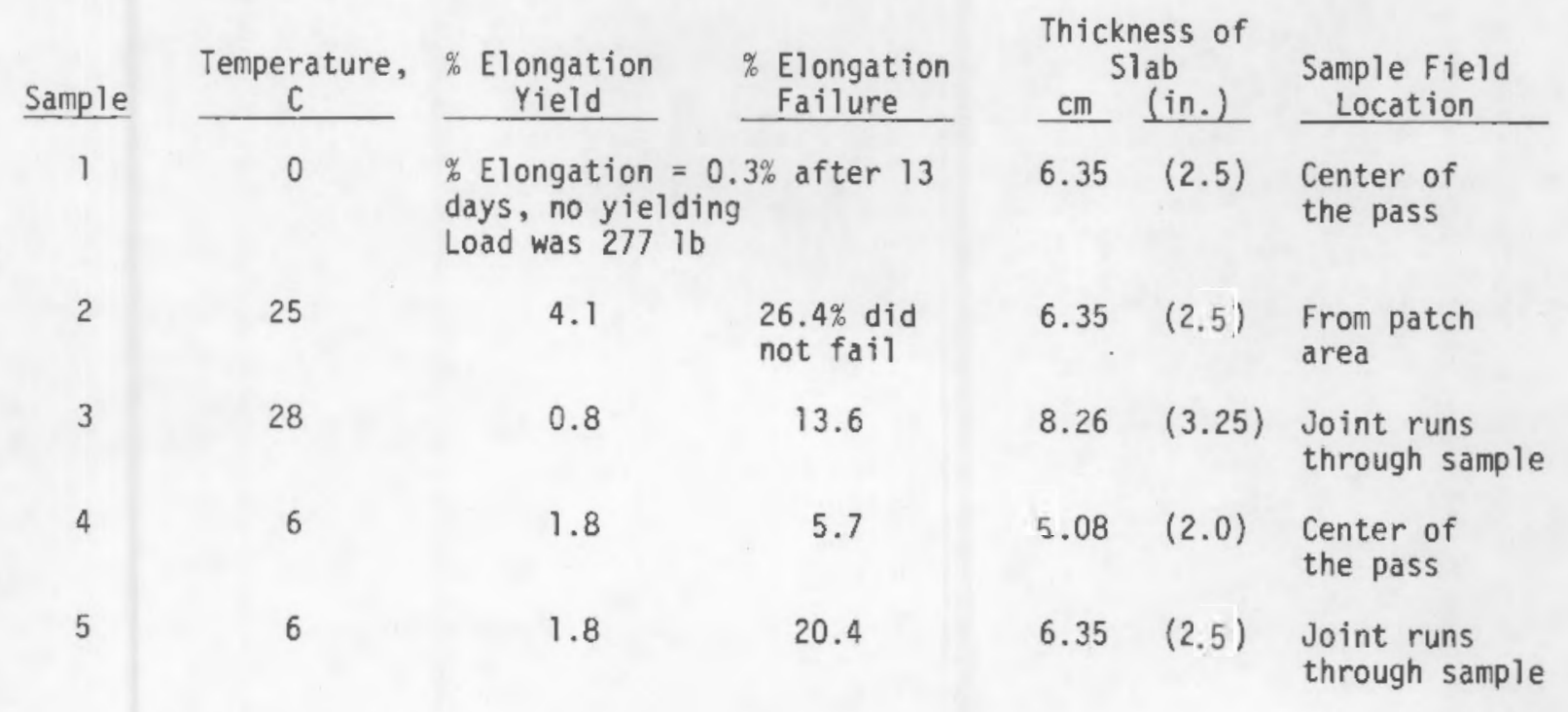


modulus of the material in bending. Modulus of rupture values for the asphaltic admix seal, at various temperatures, are given in Table 4 and shown graphically in Figure 11. A procedure similar to ASTM C78-75, "Flexural Strength of Concrete (Using Simple Beam with Third-Point Loading)", was used with a constant strain rate of $0.32 \mathrm{in}$. per minute for all tests. This strain rate, al though not in accordance with ASTM C78, was necessary to overcome creep effects in the soft asphalt admix samples. 
TABLE 4. Flexural Strength Test ${ }^{(a)}$

\begin{tabular}{|c|c|c|c|c|c|c|c|c|c|c|c|c|}
\hline \multirow[t]{2}{*}{$\begin{array}{l}\text { Specimen } \\
\text { Number }\end{array}$} & \multirow{2}{*}{\multicolumn{2}{|c|}{$\begin{array}{c}\text { Average } \\
\text { Temperature } \\
{ }^{\circ} \mathrm{C} \quad\left({ }^{\circ} \mathrm{F}\right)\end{array}$}} & \multicolumn{2}{|c|}{$\begin{array}{c}\text { Average } \\
\text { Width }\end{array}$} & \multicolumn{2}{|c|}{$\begin{array}{l}\text { Average } \\
\text { Depth }\end{array}$} & \multicolumn{2}{|c|}{$\begin{array}{l}\text { Span } \\
\text { Length }\end{array}$} & \multirow{2}{*}{\multicolumn{2}{|c|}{$\begin{array}{l}\text { Maximum } \\
\text { Applied Load } \\
\mathrm{kPa} \text { (psi) }\end{array}$}} & \multirow{2}{*}{\multicolumn{2}{|c|}{$\begin{array}{l}\text { Modulus } \\
\text { of Rupture } \\
\mathrm{kPa} \text { (psi) }\end{array}$}} \\
\hline & & & $\mathrm{Cm}$ & (in.) & $\mathrm{Cm}$ & (in.) & $\mathrm{Cm}$ & (in.) & & & & \\
\hline 1 & 154.4 & $(68.0)$ & 5.938 & $(2.375)$ & 5.938 & $(2.375)$ & 18.098 & $(7.125)$ & 552 & (80) & 293.9 & $(42.6)$ \\
\hline 2 & 154.4 & $(68.0)$ & 5.822 & $(2.292)$ & 5.847 & $(2.302)$ & 18.098 & $(7.125)$ & 503.7 & (73) & 296.0 & $(42.9)$ \\
\hline 3 & 154.4 & $(68.0)$ & 6.668 & $(2.625)$ & 6.038 & $(2.377)$ & 18.098 & $(7.125)$ & 572.7 & (83) & 275.3 & $(39.9)$ \\
\hline 4 & 154.4 & $(68.0)$ & 5.938 & $(2.375)$ & 6.139 & $(2.417)$ & 18.098 & $(7.125)$ & 248.4 & (36) & 130.4 & $(18.9)^{(b)}$ \\
\hline 5 & 123.4 & $(50.8)$ & 6.985 & $(2.750)$ & 6.408 & $(2.523)$ & 18.098 & $(7.125)$ & 1469.7 & (213) & 598.2 & $(86.7)$ \\
\hline 6 & 123.6 & $(50.9)$ & 6.286 & $(2.475)$ & 5.761 & $(2.268)$ & 18.098 & $(7.125)$ & 1469.7 & (213) & 821.8 & $(119.1)$ \\
\hline 7 & 122.4 & $(50.2)$ & 5.715 & $(2.250)$ & 6.731 & $(2.650)$ & 18.098 & $(7.125)$ & 2290.8 & (332) & 1032.9 & $(149.7)^{(b)}$ \\
\hline 8 & 124.5 & $(51.4)$ & 5.608 & $(2.208)$ & 6.073 & (2.391) & 18.098 & $(7.125)$ & 1455.9 & (211) & 821.8 & $(119.1)$ \\
\hline 9 & 79.5 & $(26.4)$ & 6.350 & $(2.500)$ & 5.954 & $(2.344)$ & 18.098 & $(7.125)$ & 2960.1 & $(429)$ & 1535.9 & $(222.6)$ \\
\hline 10 & 79.5 & $(26.4)$ & 5.822 & $(2.292)$ & 6.391 & $(2.516)$ & 18.098 & $(7.125)$ & 2918.7 & (423) & 1434.5 & $(207.9)$ \\
\hline 11 & 79.7 & $(26.5)$ & 6.350 & $(2.500)$ & 6.243 & $(2.458)$ & 18.098 & $(7.125)$ & 4250.4 & (616) & 2003.8 & $(290.4)$ \\
\hline 12 & 79.5 & $(26.4)$ & 6.271 & $(2.469)$ & 6.457 & $(2.542)$ & 18.098 & $(7.125)$ & 4043.4 & $(586)$ & 1805.0 & $(261.6)$ \\
\hline
\end{tabular}

(a) Information provided by Debora J. Hamberg, University of New Mexico, Albuquerque, New Mexico, on August $19,1981$.

(b) Nonvalid tests according to ASTM C78 - not used for regression fit. 


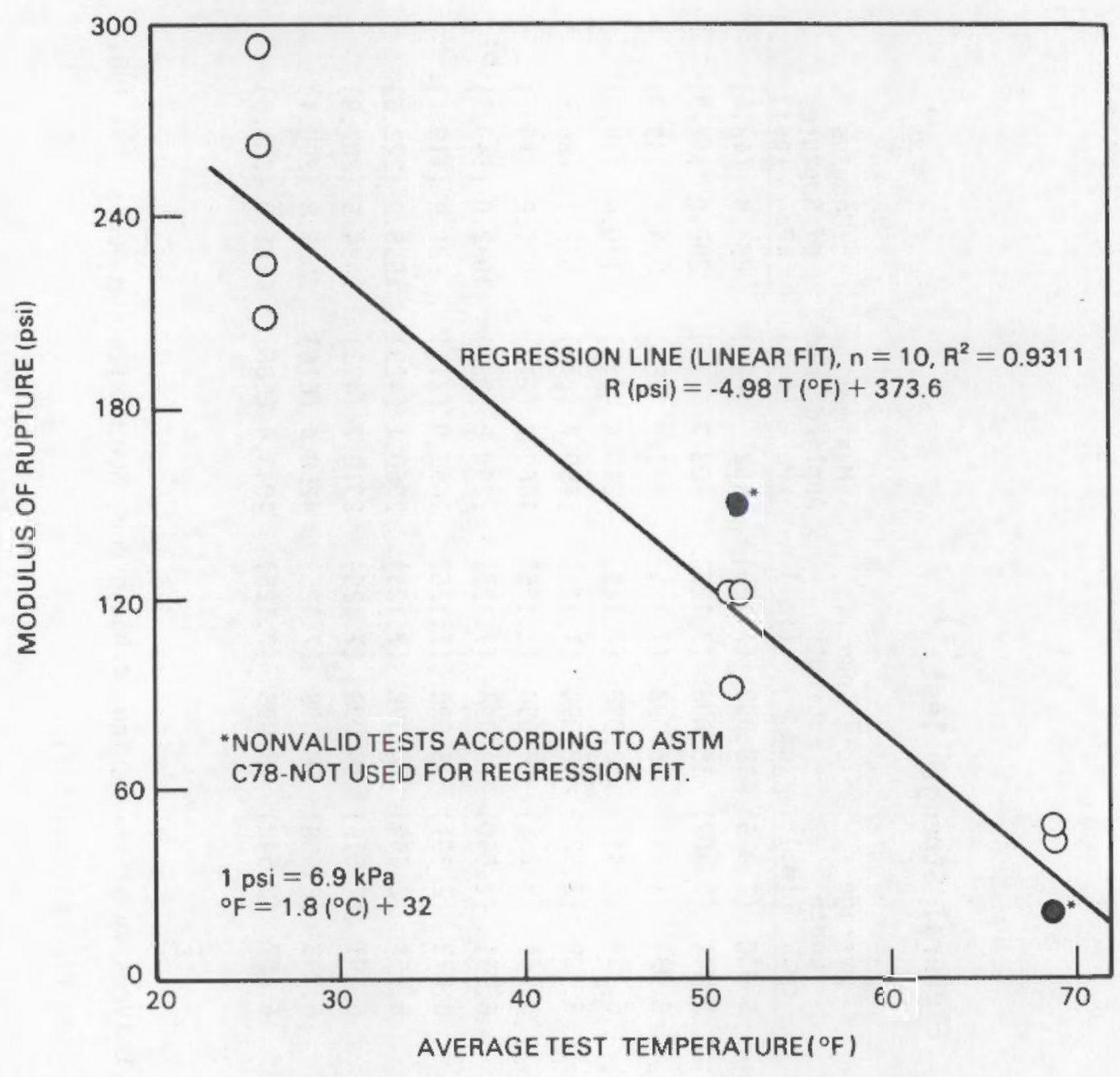

FIGURE 11. Modulus of Rupture Versus Temperature(a)

(a) Information provided by Debora J. Hamberg, University of New Mexico, Albuquerque, New Mexico, on August 19, 1981. 


\section{PERFORMANCE OF ASPHALT ADMIX SEAL}

The asphalt admix seal should be flexible. It must be able to withstand, without cracking, long-term loading stresses caused by differential settlement that can occur in the uranium mill tailings pile. In addition, the asphalt admix seal must also be resilient under short-term loading caused by shrinkage and/or swelling of the tailings pile.

\section{OIFFERENTIAL SETTLEMENT OF THE TAILINGS PILE}

Differential settlement will occur on the surface of piles due to drainage as well as stress increase resulting from cover placement. The drainage-induced settlement is due to an increase in the stress state variables resulting from an increase in the capillary tension or suction in the water. Thus, settlement of the tailings pile is due to increases in the total stress applied by the weight of the cover as well as due to increases in capillary tension as consolidation drainage takes place.

Deformation variables needed to describe changes in each phase of an unsaturated soil element can be derived from the continuity requirement for a multiphase continuum. If the soil particles are assumed incompressible and the volume change of the air-water interface is assumed internal to the element, the continuity requirement for an element reduces to:

$$
\varepsilon=\frac{\Delta V}{V}=\frac{V_{w}}{V}+\frac{\Delta V_{a}}{V}
$$

$$
\text { where } \begin{aligned}
\varepsilon & =\text { volumetric strain } \\
V & =\text { total volume } \\
V_{W} & =\text { volume of water in the element } \\
V_{a} & =\text { volume of air in the element. }
\end{aligned}
$$

Constitutive relations to link the stress deformation state variables for linear variations of the unsaturated soil properties were first proposed and 
tested by Fredlund and Morgenstern (1976). Appendix A develops the formulation of the linear consolidation equation for unsaturated soil. Constitutive relations for volume change, considering nonlinear variations of the soil properties, have been proposed by Gates (1982).

\section{ASPHALT SEAL STABILITY}

Appendix $B$ includes computations indicating the general magnitude of settlement that could be expected due to placement of a $0.76-\mathrm{m}(2.5-\mathrm{ft})$ cover system and subsequent drainage of the tailings. Similar computations have been reported by CSU (CSU 1982); however, results reported herein assume a $0.76-\mathrm{m}(2.5-\mathrm{ft})$ cover thickness to correlate with results reported in the preceding section. The computations, summarized in Table 5, indicate that settlements of the magnitude of $4.92 \mathrm{~cm}(1.94$ in.) and $10.13 \mathrm{~cm}$ (3.99 in.) could occur for a tailings zone composed of $60 \%$ sands $/ 40 \%$ slimes and $100 \%$ slimes, respectively. For the slime zones, settlements may be greater from drainage than those resulting from the increase in total stress due to the weight of the cover. In addition, settlement of the slimes is expected to take place over several years, whereas settlement of the sands is expected to occur relatively rapidly.

Relatively definite boundaries between sands and slimes zones may result from deposition of tailings into pools. Because the sands and slimes settle at different rates, differential settlements may take place over relatively short distances. Hence, assuming the maximum predicted settlement of the $60 \%$

\section{TABLE 5. Expected Settlement of Tailings Pile}

\begin{tabular}{|c|c|c|c|c|}
\hline Settlement & \multicolumn{2}{|c|}{$60 \%$ Sands $/ 40 \%$ S1 imes } & \multicolumn{2}{|c|}{$100 \%$ S1 imes } \\
\hline Cover Load & $3.45 \mathrm{~cm}$ & (1.36 in.) & $4.78 \mathrm{~cm}$ & (1.88 in.) \\
\hline Drainage & $1.47 \mathrm{~cm}$ & (0.58 in.) & $5.36 \mathrm{~cm}$ & (2.11 in.) \\
\hline TOTAL & $4.92 \mathrm{~cm}$ & (1.94 in.) & $10.14 \mathrm{~cm}$ & (3.99 in. \\
\hline
\end{tabular}


sands $/ 40 \%$ slimes, it is important to know the minimum span the asphalt admix seal could manage and the allowable elongation that results. Figure 12 is a plot of precentage elongation versus span, assuming a total deflection of 4.92 $\mathrm{cm}$ (1.94 in.) at the center. Using the worst case, the minimum span length that the asphalt admix seal could withstand without failing is $0.34 \mathrm{~m}$ (1.1 $\mathrm{ft}$ ). The seal would presumably rupture if differential settlement resulted in a span shorter than $0.34 \mathrm{~m}(1.1 \mathrm{ft})$. This finding is illustrated in Figure 13.

None of the samples tested would reach its yield point at spans greater than $0.60 \mathrm{~m}(1.97 \mathrm{ft})$. The results neglect the membrane stresses and possible scaling effects.

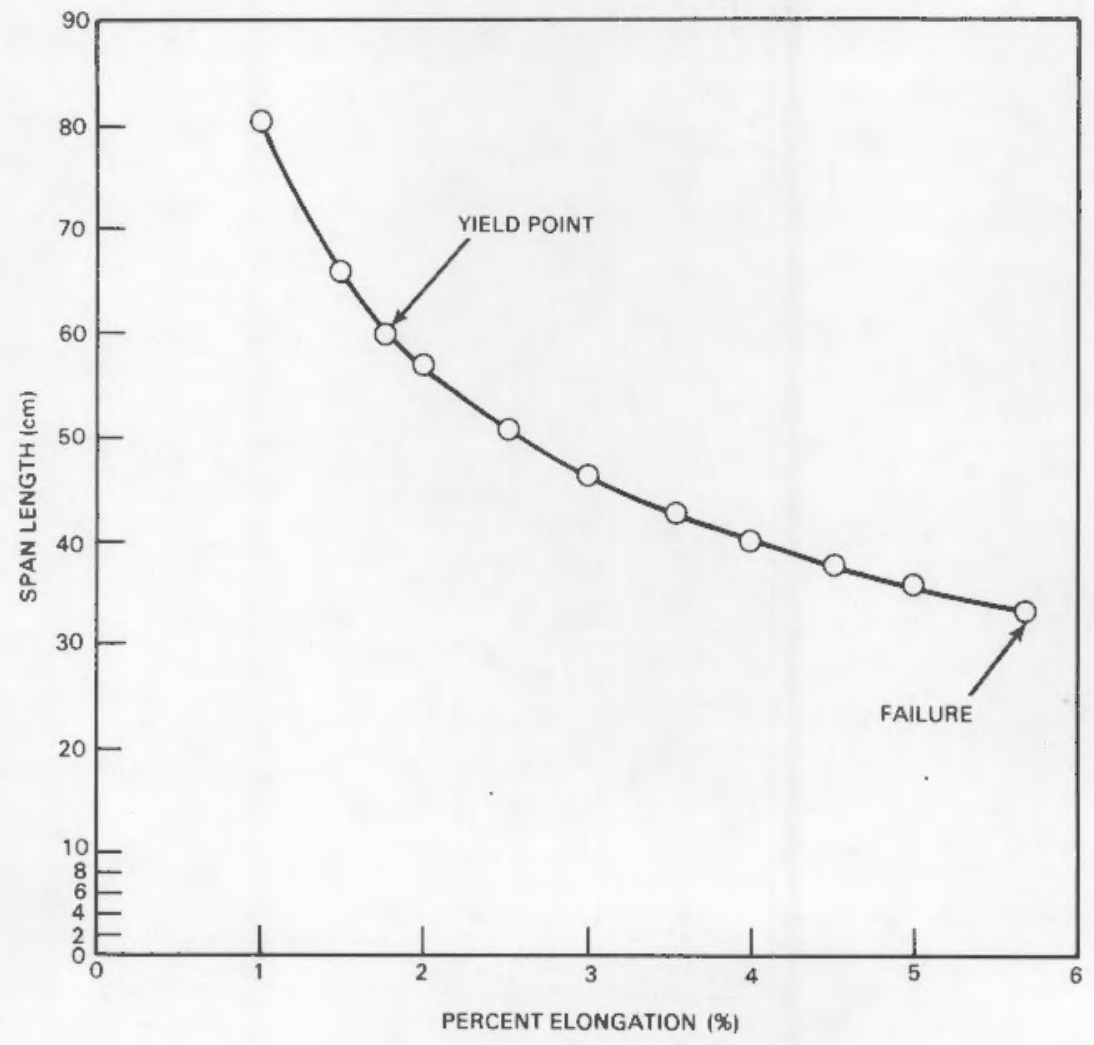

FIGURE 12. Percentage Elongation Versus Span 


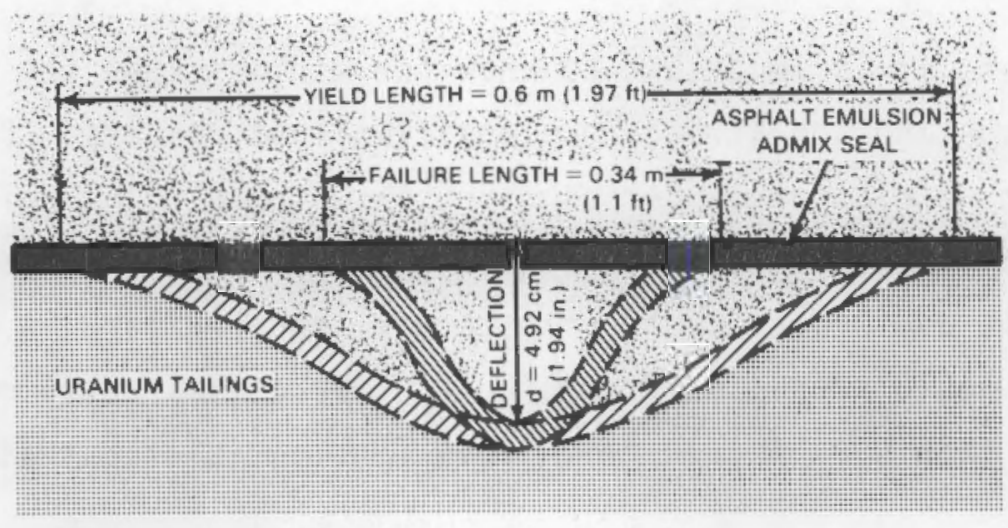

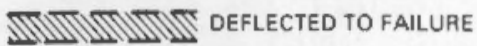

ZIITUTDL DEFLECTEO TO YIELO POINT

FIGURE 13. Limits of Asphalt Admix Seal Stability Under Worst-Case Differential Settlement 


\section{REFERENCES}

Abraham, H. 1945. Asphalt and Allied Substances. D. Van Nostrand Company, Inc., New York, New York.

Annual Book of ASTM Standards, Part 14, 1980. American Society for Testing and Materials, Philadelphia, Pennsylvania.

Baker, E. G., et al. 1983. Asphalt Emulsion Radon Barrier Systems for Inactive Uranium Mill Tailings: An Overview of the Technology, PNL-4840, Pacific Northwest Laboratory, Richland, Washington.

Colorado State University. 1980. "Inactive Uranium Mill Tailings Sites Analysis of Stability." Quarterly Report July 1980 - September 1980. Civil Engineering Department, Colorado State University, Fort Collins, Colorado.

Colorado State University. 1982. "Technology Development Report to the TAC." UMTRAP Technology Development Program Report. Civil Engineering Department, Colorado State University, Fort Collins, Colorado.

Fredlund, D. G. 1979. "Second Canadian Geotechnical Colloquium: Appropriate Concepts and Technology for Unsaturated Soils." Can. Geotech. J. $16: 121-139$.

Fredlund, D. G., and N. R. Morgenstern. 1976. "Constitutive Relations for Volume Change in Unsaturated Soils." Can. Geotech. J. 13(3):261-276.

Gates, T. E. 1982. Consolidation Theory and Its Applicability to the Dewatering and Covering of Uranium Mill Tailings. NUREG/CR-2894, U.S. Nuclear Regulatory Commission, Washington, D.C.

Hartley, J. N., G. W. Gee, E. G. Baker, and H. D. Freeman. 1983.1981 Radon Barrier Field Test at Grand Junction Uranium Mill Tailings Pile.

DOE/UMT-0213, PNL-4539, Pacific Northwest Laboratory, Richland, Washington.

Hartley, J. N., P. L. Koehmstedt, D. J. Esterl, and H. D. Freeman. 1980. Asphalt Emulsion Sealing of Uranium Mill Tailings 1979 Annual Report. PNL-3290, Pacific Northwest Laboratory, Richland, Washington.

Hartley, J. N., P. L. Koehmstedt, D. J. Esterl, H. D. Freeman, J. L. Buelt, D. A. Nelson, and M. R. Elmore. 1981. Asphalt Emulsion Sealing of Uranium Mill Tailings 1980 Annual Report. DOE/UMT-0201, PNL-3752, Pacific Northwest Laboratory, Richland, Washington.

Mittal, H. K. 1974. Design and Performance of Tailings Dams. Ph.D. Thes is, Department of Civil Engineering, The University of Alberta, Edmonton, Alberta, Canada. 
Spangler, M. G., and R. L. Handy. 1973. Soil Engineering. Intext Educational Publishers, New York, New York.

Van Zyl, D., and A. MacG. Robertson. 1980. "Subsurface Drainage of Tailings Impoundments: Some Design, Construction, and Management Considerations." In Proceedings of the Third Symposium Uranium Mill Tailings Management, pp. 153-177, Colorado State University, Fort Collins, Colorado. 
APPENDIX A

FORMULATION OF CONSOLIDATION EQUATIONS 


\section{APPENDIX A}

\section{FORMULATION OF CONSOL IDATION EQUATION}

Consider a saturated soil that is partially elastic and obeys Hooke's law. The compressibility of the soil is given by:

$$
\left.C_{C}=\frac{\Delta e}{\Delta(\log )} \overline{\bar{\sigma}_{V}}\right)
$$

where $C_{C}=$ compression index, i.e., slope of void ratio versus logarithm of vertical stress curve

$$
\begin{aligned}
e & =\text { void ratio } \\
\bar{\sigma}_{v} & =\text { vertical stress. }
\end{aligned}
$$

For partially saturated soils a similar relationship holds where $C_{t}$ is the compression index with respect to the total stress $\left(\sigma-\mu_{a}\right)$ and $C_{m}$ is the compression index with respect to matrix suction $\left(\mu_{a}-\mu_{w}\right)$; i.e.:

$$
c_{t}=\frac{\log \left[\left(\sigma-\mu_{\mathrm{a}}\right)_{0}+\Delta(\sigma)\right.}{\left.\left.\frac{\Delta e}{-\mu_{\mathrm{d}}}\right)\right]-\log \left(\sigma-\mu_{\mathrm{a}}\right)_{0}}
$$

and

$$
C_{m}=\frac{\Delta e}{\log \left[\left(\mu_{d}-\mu_{w}\right)_{0}+\Delta\left(\mu_{a}-\mu_{w}\right)\right]-\log \left(\mu_{d}-\mu_{w}\right)_{0}}
$$

where $\sigma=$ applied stress

$$
\begin{aligned}
& \mu_{\mathrm{d}}=\text { pore-air pressure } \\
& \mu_{\mathrm{W}}=\text { pore-water pressure. }
\end{aligned}
$$

The volume strain, $\varepsilon_{v}$, for a soil is given by:

$$
E_{v}=\frac{\Delta e}{1+e_{0}}
$$

where $e_{0}=$ initial void ratio. 
Substituting in terms of $C_{t}$ and $C_{m}$, Equation (4) becomes:

$$
\begin{aligned}
\varepsilon_{v} & =\frac{C_{t}\left\{\log \left[\left(\sigma-\mu_{a}\right)_{0}+\Delta\left(\sigma-\mu_{a}\right)\right]-\log \left(\sigma-\mu_{a}\right)_{0}\right\}}{1+e_{0}} \\
& +\frac{C_{m}\left\{\log \left[\left(\mu_{a}-\mu_{w}\right)_{0}+\Delta\left(\mu_{a}-\mu_{w}\right)\right]-\log \left(\mu_{a}-\mu_{w}\right)_{0}\right\}}{1+e_{0}} \\
\varepsilon_{v} & =\frac{C_{t}}{1+e_{0}} \log \frac{\left(\sigma-\mu_{a}\right)_{0}+\Delta\left(\sigma-\mu_{a}\right)}{\left(\sigma-\mu_{a} T_{0}\right.}+\frac{C_{m}}{1+e_{0}} \log \frac{\left(\mu_{a}-\mu_{w}\right)_{0}+\Delta\left(\mu_{a}-\mu_{w}\right)}{\left(\mu_{a}-\mu_{w}\right)_{0}}
\end{aligned}
$$

The deformation, $\rho$, per unit of length or strain in a body is given by the generalized Hooke's law as:

$$
\rho=\varepsilon_{v} H
$$

where $H=$ depth of pile.

Substituting Equation (5) into Equation (6), the one-dimensional consolidation of a partially saturated soil resulting from an applied load and subsequent drainage is given by:

$$
\rho=\frac{C_{t} H}{1+e_{0}} \log \frac{\left(\sigma-\mu_{a}\right)_{0}+\Delta\left(\sigma-\mu_{a}\right)}{\left(\sigma-\mu_{a}\right)_{0}}+\frac{C_{m} H}{1+e_{0}} \log \frac{\left(\mu_{a}-\mu_{w}\right)_{0}+\Delta\left(\mu_{a}-\mu_{w}\right)}{\left(\mu_{a}-\mu_{w}\right)_{0}}
$$


APPENDIX B

COMPUTATION OF SETTLEMENT 


\section{COMPUTATION OF SETTLEMENT}

\section{CASE 1: $60 \%$ SANDS $/ 40 \%$ SL IMES}

Assume pile has been preloaded (16 psi). From Sherry (1982, p. 27, Table 4-1):

$$
\begin{aligned}
& C_{m}=\frac{\Delta e}{\log \frac{\left(\mu_{\mathrm{a}}-\mu_{w}\right)_{f}}{\left(\mu_{\mathrm{d}}-\mu_{\mathrm{w}}\right)_{0}}}=\frac{0.730-0.720}{\log \left(\frac{32}{16}\right)}=\underline{\underline{0.033}} \\
& C_{t}=\frac{-\frac{\Delta \mathrm{e}}{\left.\log -\mu_{\mathrm{a}}\right)_{\mathrm{f}}}}{\log \frac{0.600-0.550}{\left(\sigma-\mu_{\mathrm{a}}\right)_{0}}}=\frac{\underline{\underline{0.166}}}{\log \left(\frac{32}{16}\right)}
\end{aligned}
$$

\section{Sett lement - Cover Load $\left[\Delta\left(\sigma-\mu_{\alpha}\right)=312.5\right.$ psf $]$}

Consider tailings in single layer, with single drainage face. Given that $\gamma_{t}=120 \mathrm{pcf}, H_{t}=40 \mathrm{ft}, \gamma_{c}=125 \mathrm{pcf}, H_{c}=2.5 \mathrm{ft}$, and assuming that $\mu_{W}=0$ and the tailings are saturated initially gives:

$$
\begin{aligned}
\rho & =\frac{C_{t} H}{1+e_{0}} \log \frac{\left(\sigma-\mu_{a}\right)_{0}+\Delta\left(\sigma-\mu_{a}\right)}{\left(\sigma-\mu_{a}\right)_{0}} \\
& =\frac{(0.166)(40}{1+0.600} \frac{\mathrm{ft})}{0.0 g}\left[\frac{(4800 \mathrm{psf})+(312.5 \mathrm{psf})}{(4800 \mathrm{psf})}\right] \\
\rho & =1.36 \mathrm{in} .(3.45 \mathrm{~cm})
\end{aligned}
$$

Note: The term $\Delta\left(\sigma-\mu_{a}\right)$ does not account for the pore-air pressure; however, the resulting error is small and the number given above conservative.

Settlement - Drainage

Using test data from Sherry (1982, p. 27, Table 4-1), the applied stress, $\sigma=312.5$ psf, will produce a change in matrix suction, $\Delta\left(\mu_{a}-\mu_{w}\right)=2.5 \mathrm{psi}$. This assumes that $\left(\mu_{\mathrm{a}}-\mu_{w}\right)_{0}=16 \mathrm{psi}$. The settlement due to drainage is: 


$$
\begin{aligned}
\rho & =\frac{C_{m} H}{1+e_{0}} \log \frac{\left(\mu_{a}-\mu_{w}\right)_{0}+\Delta\left(\mu_{a}-\mu_{W}\right)}{\left(\mu_{a}-\mu_{w}\right)_{0}} \\
& =\frac{(0.033)(40 \mathrm{ft})}{1+0.730} \log \left[\frac{(16 \mathrm{psi})+(2.5 \mathrm{psi})}{(16 \mathrm{ps} i)}\right] \\
\rho & =0.58 \mathrm{in} .(1.47 \mathrm{~cm})
\end{aligned}
$$

$\therefore$ The total settlement resulting from the cover load and subsequent drainage of the pile is $\rho=1.94 \mathrm{in} .(4.92 \mathrm{~cm})$ for a tailings pile composed of a $60 \%$ sands $/ 40 \%$ slimes mixture.

\section{CASE 2: $100 \%$ SLIMES}

Assume pile has been preloaded (16 psi). From Sherry (1982, p. 52, Table 4-3):

$$
\begin{aligned}
& C_{m}=\frac{1.911-1.850}{\log \left(\frac{32}{16}\right)}=\underline{\underline{0.203}} \\
& C_{t}=\frac{1.460-1.354}{\log \left(\frac{32}{16}\right)}=\underline{\underline{0.352}}
\end{aligned}
$$

Settlement - Cover Load, $\left[\Delta\left(\sigma-\mu_{a}\right)=312.5\right.$ psf $]$

Using the same assumptions and Note as in Case 1:

$$
\begin{aligned}
& \rho=\frac{(0.352)(40 \mathrm{ft})}{1+1.46} \log \left[\frac{(4800 \mathrm{psf})+(312.5 \mathrm{psf})}{(4800 \mathrm{psf})}\right] \\
& \rho=1.88 \mathrm{in} .(4.78 \mathrm{~cm})
\end{aligned}
$$

\section{Sett lement - Drainage}

Using test data from Sherry (1982, p. 52, Table 4-3), the applied stress, $\sigma=312.5$ psf, will produce a change in matrix suction, $\Delta\left(\mu_{\mathrm{a}}-\mu_{\mathrm{w}}\right)=2.5 \mathrm{psi}$. This assumes that $\left(\mu_{\mathrm{a}}-\mu_{\mathrm{w}}\right)_{0}=16 \mathrm{psi}$. The settlement due to drainage is: 


$$
\begin{aligned}
& \rho=\frac{(0.203)(40 \mathrm{ft})}{1+1.911} \log \left[\frac{(16 \mathrm{psi})+(2.5 \mathrm{psi})}{(16 \mathrm{psi})}\right] \\
& \rho=2.11 \text { in. }(5.36 \mathrm{~cm})
\end{aligned}
$$

$\therefore$ The total settlement resulting from the cover load and subsequent drainage of the pile is $\rho=3.99 \mathrm{in} .(10.13 \mathrm{~cm})$ for a tailings pile composed of $100 \%$ slimes.

\section{REFERENCE}

Sherry, G. P. 1982. Constitutive Relationships for Unsaturated Uranium Mill Tailings. Masters Thesis, Department of Civil Engineering, Colorado State University, Fort Collins, Colorado. 

DOE/UMT -0215

PNL -4846

UC -70

\section{DISTRIBUTION}

No. of

Copies

OFFSITE

27 DOE Technical Information Center

William E. Mott, Director

Environmental Safety Engineering

Division

U.S. Department of Energy, EP-14

Washington, DC 20545

J. E. Baublitz, Director

Division of Remedial Action Projects

Office of Nuclear Waste Management.

U.S. Department of Energy NE-301

Washington, DC 20545

E. Delaney

Division of Remedial Action Projects

Office of Nuclear Waste Management

U.S. Department of Energy, NE-301

Washington, DC 20545

D. H. Groelsema

Division of Remedial Action Projects

Office of Nuclear Waste Management

U.S. Department of Energy, NE-301

Washington, DC 20545

A. Kluk

Division of Remedial Action Projects Office of Nuclear Waste Management

U.S. Department of Energy, NE-301

Washington, DC 20545

M. G. White

Division of Remedial Action Projects Office of Nuclear Waste Management U.S. Department of Energy, NE-301 Washington, DC 20545
No. of

Copies

J. White, Chief

Reactor Operations Branch

U.S. Oepartment of Energy

Richland Operations office

P.0. Box 500

Richland, WA 99352

E. L. Keller, Director

Technical Services Division

DOE Oak Ridge Operations

Office

P.0. Box E

Oak Ridge, TN 37830

Office of the Assistant Manager for Energy Research and Development DOE Oak Ridge Operations Office

P.D. Box E

Dak Ridge, TN 37830

J. A. Morley, Project Manager

Uranium Mill Tailings Project Office

Suite 1700

5301 Central Ave. NE

Albuquerque, NM 87108

M. L. Matthews, Project Engineer

Uranium Mill Tailings Project Office Suite 1700

5301 Central Ave., NE

Albuquerque, NM 87108

R. A. Scarano, Chief

Uranium Recovery License Branch

Mail Station 483-SS

U.S. Nuclear Regulatory Commission

Washington, DC 20555 
No. of

Copies

W. A. Nixon

Office of Nuclear Materials, Safety and Safeguards

Mail Station 396-SS

U.S. Nuclear Regulatory Commission

Washington, DC 20555

G. Gnugnoli

Mail Station 1130-SS

U.S. Nuclear Regulatory

Commission

Washington, DC 20555

F. Swanberg

U.S. Nuclear Regulatory Commission

Mail Station 1120-SS

Washington, DC 20555

S. Lichtman

Criteria and Standards Division

Office of Radiation Programs

Environmental Protection Agency

Washington, OC 20460

R. F. Overmyer

Ford Bacon and Davis

P.0. Box 8009

Salt Lake City, UT 84108

T. E. Hakonson

Los Alamos Scientific Laboratory

P.0. Box 1663

Los Alamos, NM 86544

W. E. Kislieleski

Argonne National Laboratory

9700 South Cass Avenue

Argonne, IL 60439

T. N. Narasimhan

Lawrence Berkeley Laboratory Berkeley, CA 94720
No. of

Copies

W. C. Barber

Jacobs Engineering Group, Inc.

Suite 1700

5301 Central Ave. NE

Albuquerque, NM 87108

K. R. Krishnan

Program Manager

Jacobs Engineering Group, Inc.

Suite 1700

5301 Central Ave. NE

Albuquerque, NM 87108

20

R. Petersen

Document Control

Jacobs Engineering Group, Inc.

Suite 1700

5301 Central Ave. NE

Albuquerque, NM 87108

D. A. Emilia

Advanced Technology 0ivision

Bendix Field Engineering Corp.

P.0. Box 1569

Grand Junction, C0 81502

0. D. Markham

Radiological and Environmental

Sciences Laboratory

P.0. Box 2108

Idaho Falls, ID 83401

G. Markos

Research Institute for Geochemistry and Environmental Chemistry

2693 Commerce Road

Rapid City, SD 57701

J. D. Nelson

Professor, Program Leader

Colorado State University

Fort Collins, C0 80523

F. W. Whicker

Radiology Radiation

Biology Department

Colorado State University

Fort Collins, CO 80527 
No. of

Copies

J. Dybalski

Armak Research

8401 W. 47th Street

McCook, IL 60525

R. Dunning

Petroleum Sciences, Inc.

N 4817 Freya Street \#3

Spokane, WA 99207

B. Rawles

Battelle Memorial Institute

Office of Nuclear Waste Isolation

505 King Avenue

Columbus, $\mathrm{OH} 43201$

V. C. Rogers

Rogers \& Associates Engineering

P.0. Box 330

Salt Lake City, UT 84110
No. of

Copies

ONSITE

Richland Operations Office

H. E. Ransom/J. C. White

3 Rockwell Hanford Operations

H. E. McGuire

J. W. Patterson

S. A. Wiegman

41 Pacific Northwest Laboratory

E. G. Baker

P. A. Beedlow

J. L. Buelt

T. D. Chikalla

A. J. Currie

M. R. Elmore

M. G. Foley

H. D. Freeman

T. E. Gates (5)

G. W. Gee (3)

J. N. Hartley (10)

P. L. Koehmstedt

J. M. Latkovich

I. C. Nelson

R. E. Nightingale

J. V. Robinson

C. F. Voss

P. C. Walkup

N. Wogman

Technical Information (5)

Publishing Coordination (2) 
